\title{
dsRNA induces apoptosis through an atypical death complex associating TLR3 to caspase-8
}

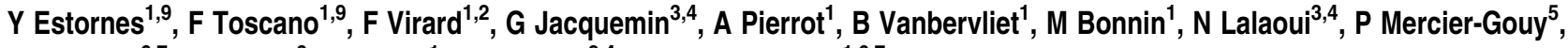 \\ Y Pachéco ${ }^{6,7}$, B Salaun ${ }^{8}$, T Renno ${ }^{1}, 0$ Micheau $^{3,4}$ and S Lebecque ${ }^{\star, 1,6,7}$
}

Toll-like receptor 3 (TLR3) is a pattern-recognition receptor known to initiate an innate immune response when stimulated by double-stranded RNA (dsRNA). Components of TLR3 signaling, including TIR domain-containing adapter inducing IFN- $\alpha$ (TRIF), have been demonstrated to contribute to dsRNA-induced cell death through caspase-8 and receptor interacting protein (RIP) 1 in various human cancer cells. We provide here a detailed analysis of the caspase-8 activating machinery triggered in response to Poly(l:C) dsRNA. Engagement of TLR3 by dsRNA in both type I and type II lung cancer cells induces the formation of an atypical caspase-8-containing complex that is devoid of classical death receptors of the TNFR superfamily, but instead is physically associated to TLR3. The recruitment of caspase-8 to TLR3 requires RIP1, and is negatively modulated by cellular inhibitor of apoptosis protein (CIAP)2-TNF receptor-associated factor (TRAF)2-TNFR-associated death domain (TRADD) ubiquitin ligase complex, which regulates RIP1 ubiquitination. Intriguingly, unlike Fas- or TRAILR-dependent death signaling, caspase-8 recruitment and activation within the TLR3 death-signaling complex appears not to be stringently dependent on Fas-associated with death domain (FADD). Our findings uncover a novel aspect of the molecular mechanisms involved during apoptosis induced by the innate immune receptor TLR3 in cancer cells.

Cell Death and Differentiation (2012) 19, 1482-1494; doi:10.1038/cdd.2012.22; published online 16 March 2012

Double-stranded RNA (dsRNA) had been known for decades for its ability to activate a strong anti-viral response through the stimulation of type I IFN (IFN-I), but also to inhibit the growth of mouse tumors. ${ }^{1}$ Moreover, the synthetic dsRNA Poly $(\mathrm{I}: \mathrm{C})$ was shown to induce caspase-8- and Fas-associated with death domain (FADD)-dependent, as well as independent cell death in human Jurkat cells, but the receptor involved was not identified. ${ }^{2}$ More recently, the endosomal membrane-bound Toll-like receptor 3 (TLR3), and the cytosolic protein kinase RNA-activated (PKR), the helicases retinoic acid-inducible gene I protein (RIG-I), and melanoma differentiation-associated protein 5 (MDA5) have been identified as dsRNA receptors that could each trigger IFN-I production and cell death, depending on the cellular context. ${ }^{3}$

TLR3 is a pattern-recognition receptor that triggers an innate immune response in the presence of dsRNA released during viral infections and possibly endogenous mRNA freed by damaged tissues. ${ }^{3}$ Upon dsRNA binding, TLR3 dimerization and reorientation of its Toll-IL-1-receptor (TIR) cytoplasmic domain leads to the recruitment of the adapter molecule TIR domain-containing adapter inducing IFN- $\alpha$
(TRIF), which recruits TNF receptor-associated factor (TRAF)-6 and the receptor interacting protein (RIP)-1 serine-threonine kinase for the activation of NF- $\kappa B$, and/or TRAF3 for the activation of IFN regulatory factor 3 and the IFN- $\alpha$ response. ${ }^{3}$ Microscopy analysis revealed that TLR3 and TRIF transiently colocalize in response to Poly $(\mathrm{I}: \mathrm{C})$ before the formation of the TRIF signaling complex. ${ }^{4}$ However, whether or not TLR3 takes part of the TRIF signalosome remains undetermined. In addition, we and others have recently demonstrated that TLR3 can trigger caspase-8dependent apoptosis in human cancers. ${ }^{5-7}$ Related to this proapoptotic function, we also found that TLR3 expressed by breast cancer cells is a biomarker for the therapeutic efficacy of dsRNA. ${ }^{8}$

Unlike classical death receptors (DRs), TLR3 lacks a death domain (DD) and thus the molecular basis of dsRNA-triggered apoptosis through caspase-8 remains an open question although recent reports indicate that TRIF and RIP1 are required for Poly(l:C) to engage the apoptotic machinery. ${ }^{5,9,10}$ Earlier experiments already suggested that a TRIF/RIP1/ caspase-8 complex may have some relevance as ectopic

\footnotetext{
${ }^{1}$ Centre de Recherche en Cancérologie de Lyon, UMR5286 CNRS/INSERM/Université Lyon 1 UCBL, Lyon, France; ${ }^{2}$ Faculté d'Odontologie, Université Lyon 1, Lyon, France; ${ }^{3}$ U866 INSERM, Dijon, France; ${ }^{4}$ Faculté de Médecine et de Pharmacie, Université de Bourgogne, Dijon, France; ${ }^{5}$ UMR 5086 CNRS/Université Lyon 1/IBCP, Lyon, France; ${ }^{6}$ Hospices Civils de Lyon, Lyon, France; ${ }^{7}$ Faculté de Médecine Lyon-Sud, Oullins, France and ${ }^{8}$ Ludwig Institute for Cancer Research, Epalinges, Switzerland

${ }^{*}$ Corresponding author: S Lebecque, Centre de Recherche en Cancérologie de Lyon, Bâtiment Cheney D, 28 rue Laennec, Lyon 69008, France.

Tel: + 334691666 26; Fax: + 334691666 60; E-mail: serge.lebecque@univ-lyon1.fr

${ }^{9}$ These authors contributed equally to this work.

Keywords: Toll-like receptor 3; apoptosis; caspase-8; RIP1; ubiquitination; cancer cells

Abbreviations: DD, death domain; DISC, death-inducing signaling complex; DR, death receptor; dsRNA, double-stranded RNA; FADD, Fas-associated with death domain; FLIPL, FLICE-like inhibitory protein; ISRE, interferon-stimulated response element; MDA5, melanoma differentiation-associated protein 5; NSCLC, non small cell lung cancer; PI, propidium iodide; PKR, protein kinase RNA-activated; RHIM, RIP homotypic interaction motif; RIG-I, retinoic acid-inducible gene I protein; RIP, receptor interacting protein; Ter, terminal; TIR, Toll-IL-1-receptor; TLR, Toll-like receptor; TRADD, TNFR-associated death domain; TRAF, TNF receptor-associated factor; TRIF, TIR domain-containing adapter inducing IFN- $\alpha$

Received 01.8.11; revised 12.1.12; accepted 08.2.12; Edited by J Silke; published online 16.3.12
} 
transfection of TRIF induced its binding RIP1 through its C-terminal RIP homotypic interaction motif $(\mathrm{RHIM})^{11}$ but also triggered apoptosis in a caspase-8-dependent manner. ${ }^{12,13}$ Conversely, cellular inhibitor of apoptosis protein (clAP)1 and clAP2 have been described as negative regulators of TLR3-induced apoptosis. ${ }^{7,9,10}$ These E3 ubiquitin ligases were recently shown to inhibit the spontaneous formation of a molecular complex termed 'Ripoptosome', containing caspase-8, caspase-10, FADD, cFLIP, and RIP1 that associates with TRIF after Poly(I:C) stimulation. ${ }^{10,14}$ While formation of this complex clearly involves TLR3 signaling, evidence of the molecular assembly of this machinery to TLR3 is lacking.

Identifying such a novel complex would be highly relevant to the understanding of the molecular events involved in Poly(I:C)-triggered apoptosis as TRIF is also known to interact with the dsRNA sensor helicases complex DDX1-DDX21$\mathrm{DHX} 36^{15}$, and with the RIGI and MDA5 adapter VISA (also known as IPS-1) ${ }^{16}$ to signal innate immune responses.

Our results clearly demonstrate that TLR3-induced cell death requires the formation of a novel complex containing TLR3 and caspase-8, and proceeds through apoptosis. Recruitment and activation of caspase- 8 to TLR3, in human cancer cells, requires RIP1 and is negatively modulated by clAPs.

\section{Results}

Poly(I:C) dsRNA induces apoptosis in NSCLC cells via the TLR3/TRIF pathway. Several NSCLC cell lines were screened for their response to Poly(I:C) at concentrations ranging from $1 \mu \mathrm{g} / \mathrm{ml}$ up to $100 \mu \mathrm{g} / \mathrm{ml}$. Some of them showed significant reduction in cell viability $(\mathrm{NCl}-\mathrm{H} 1703, \mathrm{NCl}-\mathrm{H} 292$, SK-MES-1, and NCl-H596) while others were less (SW900 and $\mathrm{NCl}-\mathrm{H} 520)$ or not sensitive ( $\mathrm{NCl}-\mathrm{H} 661)$, even when exposed for up to $72 \mathrm{~h}$ (Figure $1 \mathrm{a}$ and Supplementary Figure S1a and unpublished data). Cell viability reduction by Poly $(\mathrm{l}: \mathrm{C})$ was dose-dependent and associated with the appearance of cell death characterized by propidium iodide (PI) incorporation and cell-surface annexin $V$ binding (Figures $1 \mathrm{a}$ and $\mathrm{b}$, and Supplementary Figures $\mathrm{S} 1 \mathrm{a}$ and $\mathrm{S} 1 \mathrm{~b})$. Two sensitive cell lines $(\mathrm{NCl}-\mathrm{H} 1703$ and $\mathrm{NCl}-$ $\mathrm{H} 292)$ were chosen for further characterization. Annexin V staining was also dose-dependent (Figure 1b) and became detectable after $4 \mathrm{~h}$ of Poly $(\mathrm{I}: \mathrm{C}$ ) treatment (Supplementary Figure S1c). Electron microscopy of Poly(l:C)-treated $\mathrm{NCl}$ H292 (Supplementary Figure S1d) and $\mathrm{NCl}-\mathrm{H} 1703$ cells (data not shown) showed typical features of apoptosis, including membrane blebbing, karyorrhexis, pyknosis, and organelle condensation. Moreover, the complete prevention of annexin $\mathrm{V}$ and $\mathrm{PI}$ staining after pre-treatment with the broad-spectrum caspase inhibitor Z-VAD, and the absence of protective effect of the RIP1 kinase inhibitor necrostatin $-1^{17}$ indicate that Poly(l:C) kills NSCLC cancer cells through caspase-dependent apoptosis, without participation of necroptosis (Figure 1c).

Efficient silencing of PKR, RIG-I, and MDA5 with specific siRNA (Figure 1d) failed to protect NSCLC cells from Poly(I:C)-induced cytotoxicity (Figures 1e and f). In contrast,
siRNAs targeting either TLR3 or TRIF (the only known adapter for TLR3) (Figure 1g, and Supplementary Figure S2) suppressed Poly(I:C)-induced apoptosis and increased cell viability (Figures $1 \mathrm{e}$ and $\mathrm{h}$ ). Moreover, consistent with the requirement for endosome acidification for TLR3 signaling, the V-ATPase inhibitor bafilomycin-A1 inhibited Poly(I:C)-induced apoptosis (Supplementary Figure S1e). Noteworthy, in the presence of Z-VAD, TLR3 activation induced NF- $\kappa \mathrm{B}$ - and ISRE-dependent transcription, as shown by luciferase reporter activities (Supplementary Figure S1f), which were blocked by TLR3 siRNA (unpublished data). We conclude that Poly $(\mathrm{I}: \mathrm{C})$ can both activate the innate immune response and kill cancer cells through the TLR3/TRIF signaling pathway.

TLR3 activation triggers apoptosis through the extrinsic pathway. In line with annexin V staining (Supplementary Figure S1c), activation of caspase-8 (p43/p41 and p18 fragments) and caspase-3 (p20, p17, and p12 fragments) was detected by western blot $2 \mathrm{~h}$ after addition of Poly $(\mathrm{I}: \mathrm{C})$ in both cell lines, and coincided with the cleavage of Bid and PARP (Figure 2a). Caspase-9 was also activated, as shown by the appearance of its p37/p35 fragments (Figure 2a), but to a much lower extent in $\mathrm{NCl}$ $\mathrm{H} 292$ as compared with $\mathrm{NCl}-\mathrm{H} 1703$ cells.

Caspase-8 siRNA abrogated apoptosis in both cell lines, whereas caspase-9 knockdown only partially protected $\mathrm{NCl}$ $\mathrm{H} 1703$ cells and failed to rescue $\mathrm{NCl}-\mathrm{H} 292$ cells (Figures $2 \mathrm{~b}$ and $\mathrm{c}$ ). In line with a dominant role for caspase-8, overexpression of the FLICE-like inhibitory protein (FLIP $\mathrm{L}_{\mathrm{L}}$ protected both cell lines (Figures $2 d-f$ ). Overexpression of $\mathrm{Bcl}-\mathrm{xL}$ or Bcl-2 inhibited both TLR3- and TRAIL receptordependent apoptosis in $\mathrm{NCl}-\mathrm{H} 1703$ cells, but had no effect in $\mathrm{NCl}-\mathrm{H} 292$ (Figures 2d-f), indicative that $\mathrm{NCl}-\mathrm{H} 1703$ and $\mathrm{NCl}-\mathrm{H} 292$ cells are type II and type I cells, respectively. Collectively, these data show that caspase- 8 is the main initiator caspase involved in TLR3-triggered apoptosis in our model.

Activation of TLR3 induces the formation of a caspase-8activating DISC-like complex independently of classical DRs. We then investigated the possibility that a deathinducing signaling complex (DISC)-like might occur after Poly(I:C) treatment. Size-exclusion chromatography showed that full-length and cleaved caspase-8 shifted to high molecular weight fractions $2 \mathrm{~h}$ after TLR3 activation (Supplementary Figure S3). Moreover, caspase-8 physically associated with FADD, caspase-10 (only expressed in $\mathrm{NCl}-\mathrm{H} 292$ cells), and FLIP $_{\mathrm{L}}$ after Poly(I:C) treatment (Figure 3a). Caspase-8 immunoprecipitates showed progressive processing of caspase-10 and FLIP , as described in Fas- and TRAIL receptor-associated DISCs. ${ }^{18,19}$

We then asked whether TLR3 triggered apoptosis directly or through the secondary activation of other DRs. NCl-H1703 (resistant to Fas) and $\mathrm{NCl}-\mathrm{H} 292$ (resistant to TNF- $\alpha$ ) cells were not protected by blocking antibodies targeting TRAIL, TNF- $\alpha$, or Fas (Supplementary Figure S4a). In addition, suppression of TNFRI expression with siRNA did not protect the cells (Supplementary Figures S4b and S4c), confirming that this receptor was not involved at any level in 
Poly(I:C)-triggered cell death. Consistently, neither Fas, or DR4/DR5, nor TNFRI was associated with caspase-8 after TLR3 activation (Figure $3 \mathrm{~b}$ ).

Both TRIF and TLR3 associate with caspase-8 after Poly(I:C) stimulation. As DRs are not involved in the formation of the caspase-8-containing death complex, we wondered whether TRIF and TLR3 were present in the caspase-8 immunoprecipitates after Poly(I:C) stimulation. Interestingly, we found that both TRIF and TLR3 physically associated with caspase-8 as early as $10 \mathrm{~min}$ and up to $6 \mathrm{~h}$ after Poly(l:C) addition (Figure 4a). To confirm that TLR3 and TRIF interact physically with this DISC-like complex, TRIF was immunoprecipitated after addition of Poly $(I: C)$ a

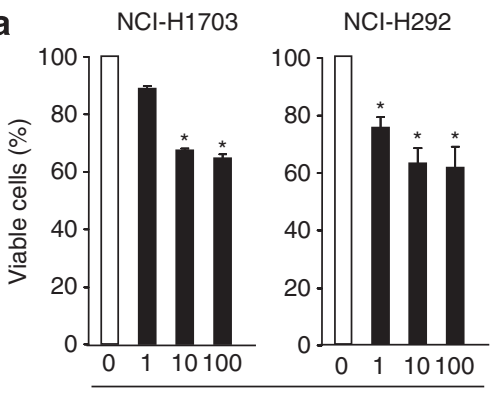

Poly(l:C) $(\mu \mathrm{g} / \mathrm{ml})$ for $24 \mathrm{~h}$

C

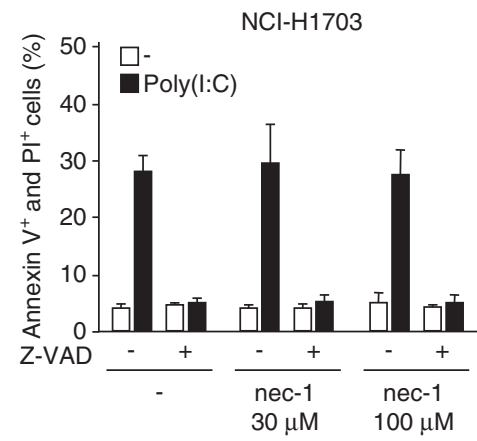

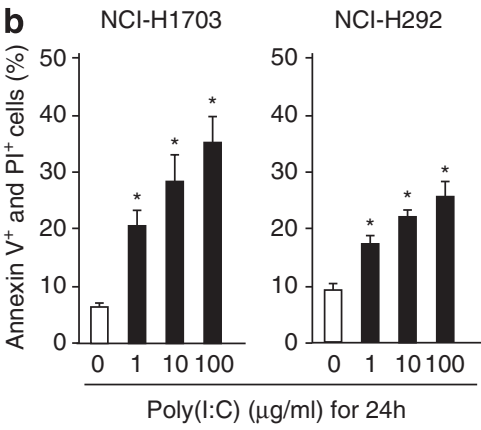

$\mathrm{NCl}-\mathrm{H} 292$

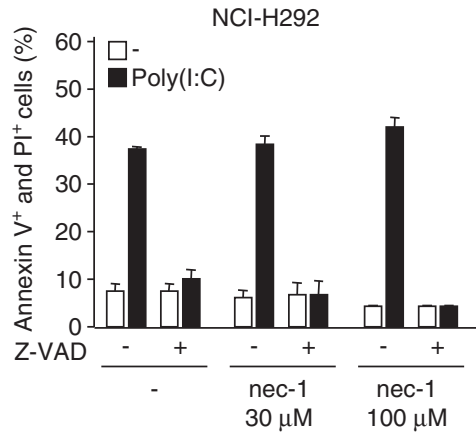

d

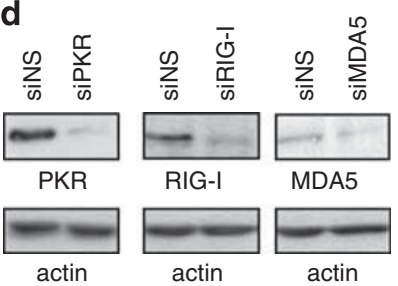

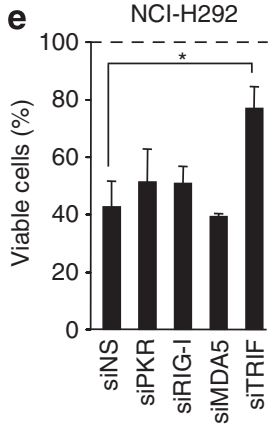

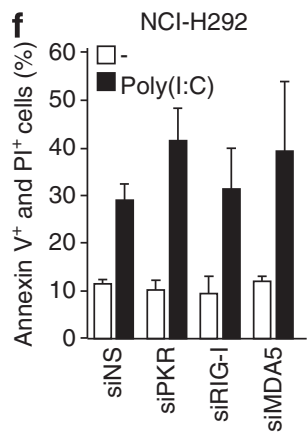

g

$\mathrm{NCl}-\mathrm{H} 1703 \quad \mathrm{NCl}-\mathrm{H} 292 \quad \mathbf{h}$
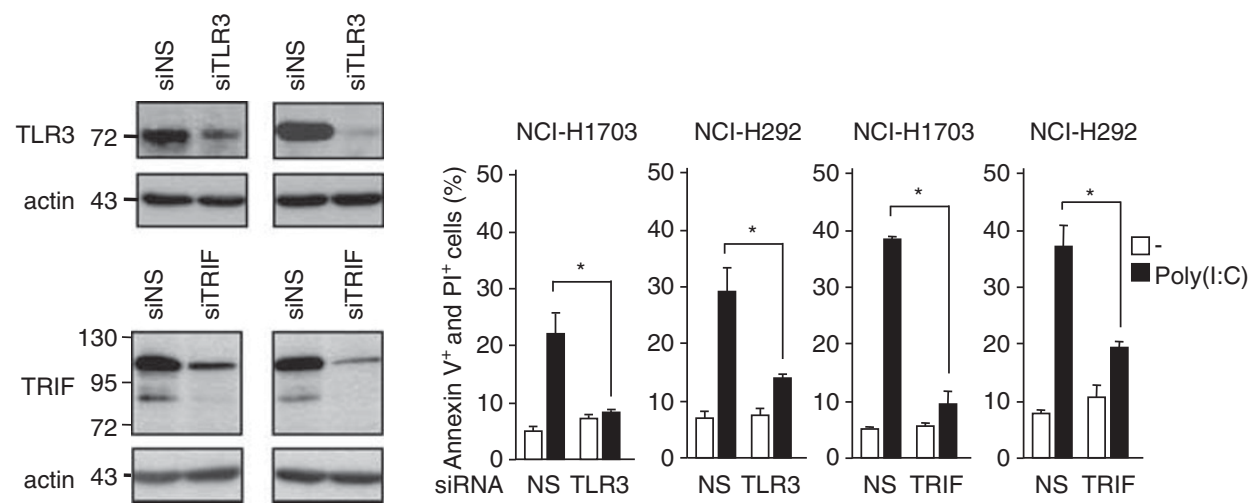
(Figure 4b). Consistent with caspase-8 co-immunoprecipitation experiments, TLR3 and caspase- 8 were detected associated with TRIF as early as $30 \mathrm{~min}$ after Poly(I:C) stimulation. Interestingly, by $2 \mathrm{~h}$, the amount of full-length TRIF started to decrease in cell lysates, while an $\sim 34-\mathrm{kDa}$ fragment, probably representing the $\mathrm{N}$-terminal (N-Ter) fragment of TRIF after caspase cleavage,${ }^{20}$ became visible (Figure 4b). However, this cleaved product could not be detected in caspase-8 immunoprecipitates (unpublished data) likely because the TRIF antibody used here recognizes residues located at the $\mathrm{N}$-Ter side of the reported caspase cleavage sites (D281 and D289), ${ }^{20}$ whereas the TIR and RHIM domains are on the C-Ter side. Therefore, our data suggest that TRIF is cleaved in the TLR3 signaling complex, and that the generated N-Ter fragment does not remain associated with caspase-8. Taken together, our data indicate that $\mathrm{Poly}(\mathrm{l}: \mathrm{C})$ triggers the formation of a TLR3-to-caspase 8 complex independent of classical DRs.

RIP1 is required for the formation of the caspase-8containing complex and undergoes post-translational modifications. RIP1 is known to contribute to the TLR3 inflammatory signaling through its ability to interact with TRIF. ${ }^{11}$ By co-immunoprecipitation experiments, we first confirmed that RIP1 associates with TRIF upon TLR3 engagement in our cell lines (Supplementary Figure S5). Interestingly, we found that RIP1 not only associates with caspase-8 after Poly(I:C) addition (Figure 5a) but is required for apoptosis triggering as inactivation of RIP1 expression using siRNAs suppressed almost completely TLR3-mediated apoptosis (Figure 5b). Moreover, RIP1 depletion impaired caspase-8 activation and prevented the recruitment of caspase- 8 to TLR3 and TRIF, and its association with FADD (Figure $5 \mathrm{c}$ ). Beside the $78-\mathrm{kDa}$ full-length RIP1 associated with caspase- 8 in this complex, a $43-\mathrm{kDa}$ band was observed that could correspond to a caspase-8-dependent cleaved product of RIP1, as reported for TNFRI, ${ }^{21}$ as this band was enriched in the caspase-8 immunoprecipitates (Figure 5a), and as it was not detected after Z-VAD pretreatment (Supplementary Figure S6). Moreover, caspase-8-associated RIP1 also showed several post-translational modifications suggestive of polyubiquitination (Figure 5a), similar to those observed for TRIF-associated RIP1 (Supplementary Figure S5), and to those required for $\mathrm{NF}-\kappa \mathrm{B}$ activation by $\mathrm{TLR}^{11}$ or by TNFRI. ${ }^{22-24}$ Indeed, using an anti-ubiquitin antibody, we demonstrated that these high molecular weight forms of RIP1 corresponded to ubiquitinated RIP1 (Figure 5d). Addition of Z-VAD increased the detection of the full-length and ubiquitinated RIP1 associated with caspase-8, probably by blocking caspase- 8 activation and subsequent complex destabilization (Figure $5 d$ and Supplementary Figure S6). Altogether, our data indicate that RIP1 is required to recruit caspase-8 to TLR3, and that the ubiquitination level of RIP1 could regulate TLR3-mediated apoptosis.

The ubiquitin ligase complex TRADD-TRAF2-cIAPs negatively regulates TLR3-triggered apoptosis. Transient association of ubiquitinated RIP1 with caspase-8 correlated with the presence in the complex of ubiquitin ligases, including TRAF2 and clAP2, as well as with the adapter protein TNFR-associated death domain (TRADD) (Figure 6a, and Supplementary Figure S7). Although clAP1 is expressed in both cell lines (Figure 6e), we could not detect it in the complex after TLR3 activation (unpublished data). Of note, TRAF2 appeared to be modified at the post-translational level after Poly(I:C) stimulation in this complex (Figure 6a). Also, high molecular weight bands possibly corresponding to modified TRADD became visible in the caspase-8-associated complex in $\mathrm{NCl}-\mathrm{H} 292$ cells $120 \mathrm{~min}$ after Poly(I:C) addition (Figure 6a). In $\mathrm{NCl}-\mathrm{H} 1703$, however, similar bands were already present in resting cells, did not increase after TLR3 activation (Figure 6a), and coimmunoprecipitated with control IgG (data not shown) suggesting that they could be nonspecific.

Similar to TNFRI, ${ }^{25}$ TLR3-mediated apoptosis was increased when TRAF2 (for NCl-H292 cells), clAP2, or TRADD expressions were knocked-down (Figures $6 \mathrm{~b}$ and $\mathrm{c}$ ). Moreover, pretreatment with the small-molecule inhibitor of apoptosis protein-antagonist BV6, which triggers a rapid and specific clAP1/2 degradation (Figure 6e and Varfolomeev et al. ${ }^{25}$ ), drastically sensitized NSCLC cell lines not only to TNF- $\alpha$ but also to TLR3-induced apoptosis (Figure 6d).

\section{cIAPs-mediated RIP1 ubiquitination negatively regulates TLR3-to-caspase 8 death complex formation and apoptosis. We hypothesized that RIP1 ubiquitination might modulate caspase-8 recruitment as reported for TNFRI. ${ }^{26}$ Using RIP1 siRNA, Z-VAD, and/or necrostatin-1, we first}

Figure 1 TLR3 activation by Poly(l:C) induces apoptosis. (a) $\mathrm{NCl}-\mathrm{H} 1703$ and $\mathrm{NCl}-\mathrm{H} 292$ cells were treated for $24 \mathrm{~h}$ with $\mathrm{Poly}(\mathrm{l}: \mathrm{C})$ at the indicated concentrations, and viable cells were numbered with MTS assay and expressed as percentage of untreated cells. ${ }^{*} P<0.05$ compared with untreated cells; error bars represent S.E.M. of at least three independent experiments performed in triplicate. (b) Percentage of annexin V positive $\left(^{+}\right)$and $\mathrm{PI}^{+} \mathrm{NCl}-\mathrm{H} 1703$ and $\mathrm{NCl}-\mathrm{H} 292$ cells treated for $24 \mathrm{~h}$ with Poly(l: $\left.\mathrm{C}\right)$ at the indicated concentrations. ${ }^{*} P<0.05$ compared with untreated cells; error bars represent S.E.M. of at least three independent experiments. (c) Percentage of annexin $\mathrm{V}^{+}$and $\mathrm{PI}^{+} \mathrm{NCl}-\mathrm{H} 1703$ and $\mathrm{NCl}-\mathrm{H} 292$ cells treated for $1 \mathrm{~h}$ with $20 \mu \mathrm{M} \mathrm{Z-VAD}$ and/or necrostatin-1 (nec-1) at the indicated concentrations, and then exposed to $100 \mu \mathrm{g} / \mathrm{ml} \mathrm{Poly}(\mathrm{l}: \mathrm{C})$ for $6 \mathrm{~h}$. Error bars represent S.E.M. of three independent experiments. (d) NCl-H292 cells were transfected with non-silencing siRNA (siNS) or with siRNA targeting PKR (siPKR), RIG-I (siRIG-I), or MDA5 (siMDA5) for $72 \mathrm{~h}$, and then were lysed and immunoblotted as indicated. (e and f) NCl-H292 cells were transfected with siNS or siPKR, siRIG-I, siMDA5 or siTRIF for $72 \mathrm{~h}$, and exposed to $100 \mu \mathrm{g} / \mathrm{ml}$ Poly $(\mathrm{l}: \mathrm{C})$ for $24 \mathrm{~h}$. (e) The number of viable cells was determined and expressed as percentage of untreated cells (dotted line). (f) The percentage of annexin $\mathrm{V}^{+}$and $\mathrm{PI}^{+}$cells was measured. ${ }^{\star} P<0.05$ compared with treated siNS cells; error bars represent $\mathrm{S}$.E.M. of at least three independent experiments. (g) NCl-H1703 and NCl-H292 cells were transfected with siRNA targeting TLR3 (siTLR3) or TRIF (siTRIF), and then immunoblotted as indicated. For TLR3 immunoblot, we used a new monoclonal antibody (named TLR3.2 mAb) that we have generated and validated for its specificity against human TLR3 (Supplementary Figure S2). We detected a 72-kDa band corresponding to the recently described C-terminal fragment of TLR3 (Ewald et al. ${ }^{40}$ and unpublished data). (h) NCl$\mathrm{H} 1703$ and $\mathrm{NCl}-\mathrm{H} 292$ cells were transfected with siNS, siTLR3, or siTRIF, and exposed to $100 \mu \mathrm{g} / \mathrm{ml} \mathrm{Poly}(\mathrm{l}: \mathrm{C})$ for $6 \mathrm{~h}$. The percentage of annexin $\mathrm{V}^{+}$and $\mathrm{PI}^{+}$cells was measured. ${ }^{*} P<0.05$ compared with siNS-treated cells plus Poly $(\mathrm{l}: \mathrm{C})$; error bars represent S.E.M. of three independent experiments 

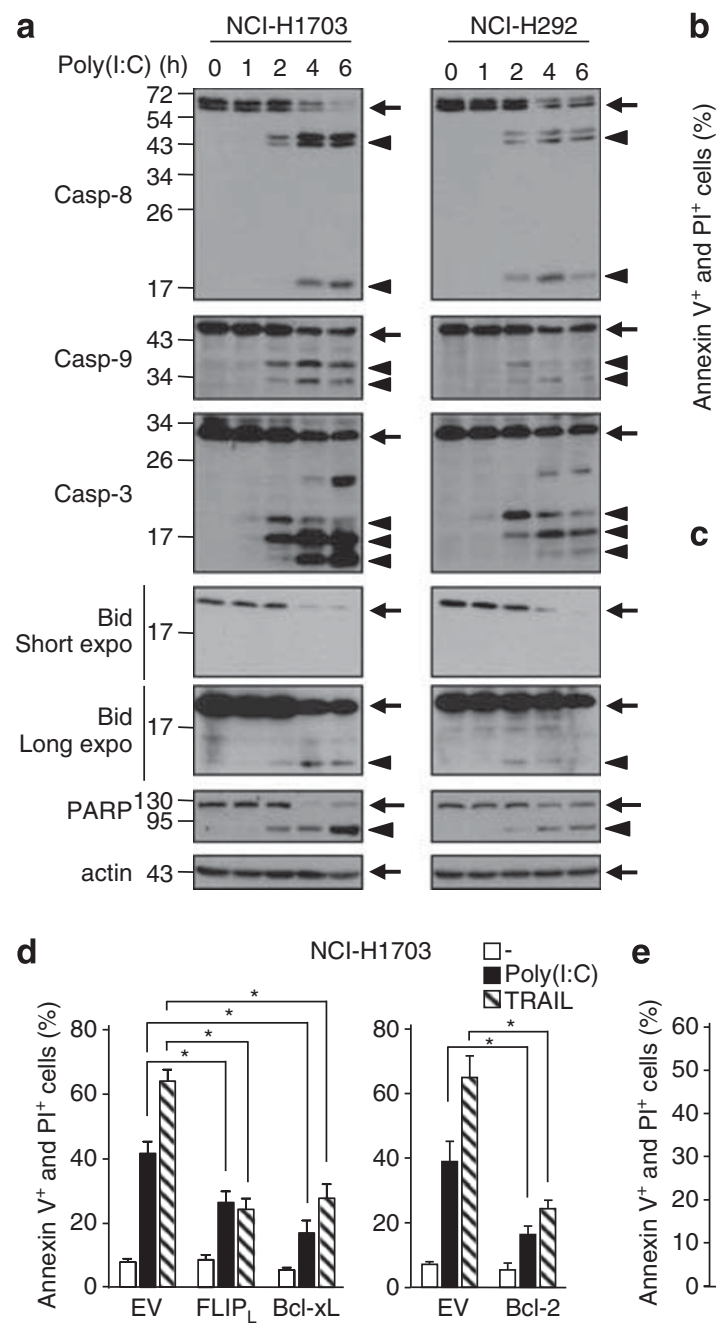

$\mathrm{NCl}-\mathrm{H} 1703$

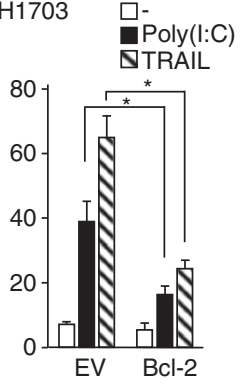

b

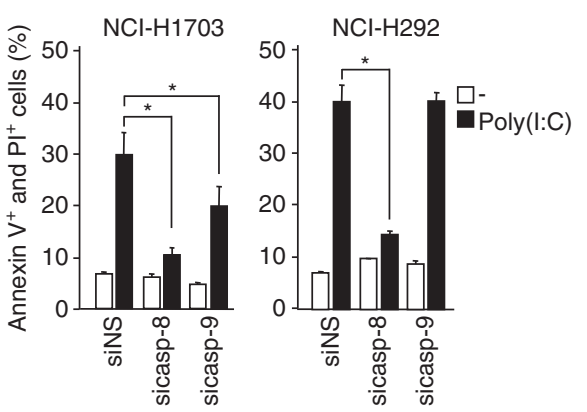

c

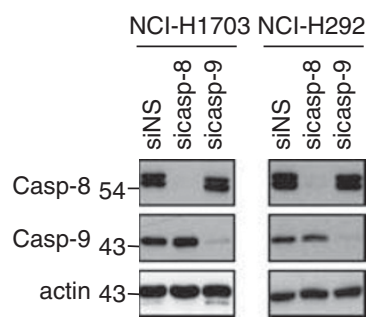

$\mathrm{NCl}-\mathrm{H} 292$
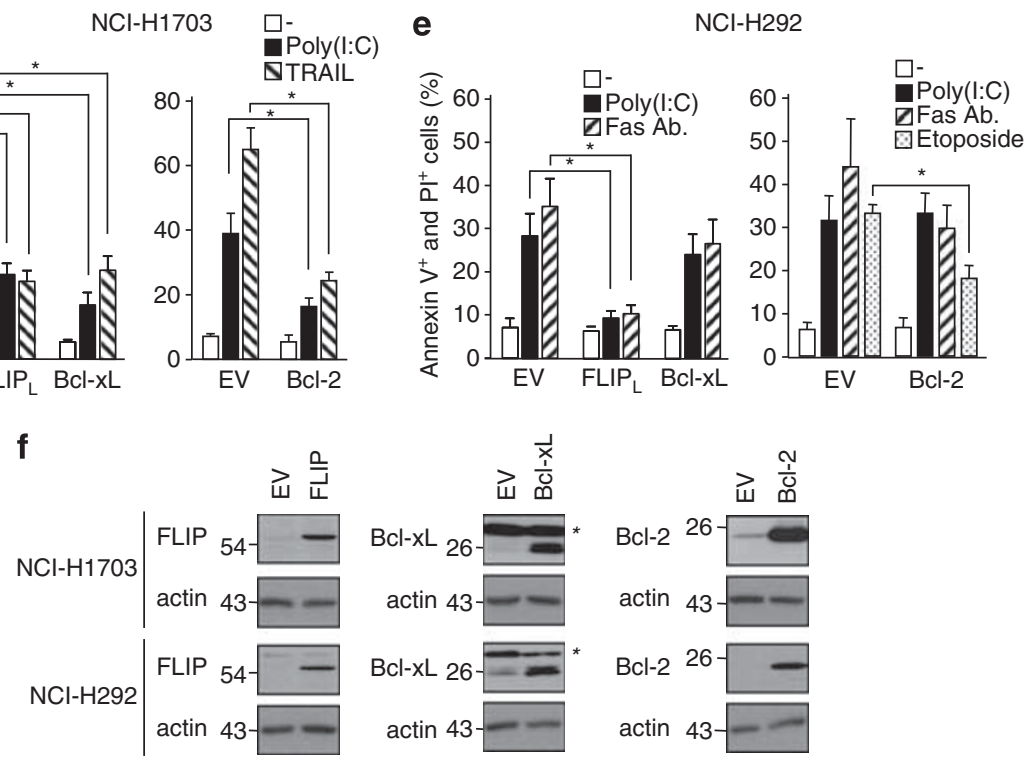

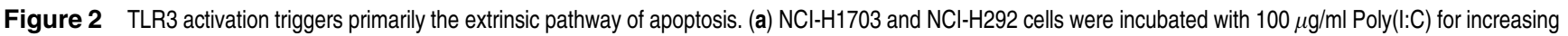
times, and then lysed and immunoblotted as indicated. Arrows and arrowheads indicate full-length and cleaved proteins, respectively. (b) $\mathrm{NCl}-\mathrm{H} 1703$ and NCl-H292 cells were transfected with siRNA targeting caspase-8 (sicasp-8) or caspase-9 (sicasp-9), exposed to $100 \mu \mathrm{g} / \mathrm{ml} \mathrm{Poly}\left(\mathrm{l}: \mathrm{C}\right.$ ) for $6 \mathrm{~h}$, and the percentage of annexin $\mathrm{V}^{+}$and PI ${ }^{+}$cells was measured. ${ }^{*} P<0.05$ compared with siNS-treated cells plus Poly(l:C); error bars represent S.E.M. of three independent experiments. (c) $\mathrm{NCl}-\mathrm{H} 1703$ and NCl-H292 cells were transfected with siRNA targeting caspase-8 or caspase-9 for $72 \mathrm{~h}$, and then were lysed and immunoblotted as indicated. (d and e) NCl-H1703 (d) and NCl-H292 (e) cells stably expressing either empty vector (EV), FLIP $\mathrm{L}^{-}, \mathrm{Bcl}-\mathrm{xL}-$, or Bcl-2-encoding vectors were exposed for $24 \mathrm{~h}$ to $100 \mu \mathrm{g} / \mathrm{ml} \mathrm{Poly}(\mathrm{l}: \mathrm{C}), 100 \mathrm{ng} / \mathrm{ml}$ TRAlL, $200 \mathrm{ng} / \mathrm{ml}$ anti-Fas antibody clone $\mathrm{CH} 11$, or $50 \mu \mathrm{M}$ etoposide, and then the percentage of annexin $\mathrm{V}^{+}$and $\mathrm{PI}^{+}$cells was measured. ${ }^{*} P<0.05$; error bars represent S.E.M. of three independent experiments. (f) $\mathrm{NCl}-\mathrm{H} 1703$ and $\mathrm{NCl}-\mathrm{H} 292$ cells stably expressing either $\mathrm{EV}, \mathrm{FLIP}_{\mathrm{L}^{-},}, \mathrm{Bcl}-\mathrm{xL}-$, or Bcl-2-encoding vectors were lysed and immunoblotted as indicated. *Indicates nonspecific band

checked that cell death triggered by the combination of Poly(I:C) plus BV6 still required RIP1 (Figure 7a), remained strictly apoptotic, and could not proceed through necroptosis, respectively (Supplementary Figure S8). When combined with Poly $(I: C)$ stimulation, loss of clAPs led to a decrease of RIP1 ubiquitination, and enhanced the association of full-length RIP1 with caspase-8, leading to increased RIP1 cleavage (Figure 7b). Of note, inactivation of clAPs using BV6 did not by itself induce RIP1 association with caspase-8. Quantifications of RIP1 immunoblot, by densitometric analysis, clearly indicated that the amounts of the cleaved and ubiquitinated forms of RIP1 associated with 
a

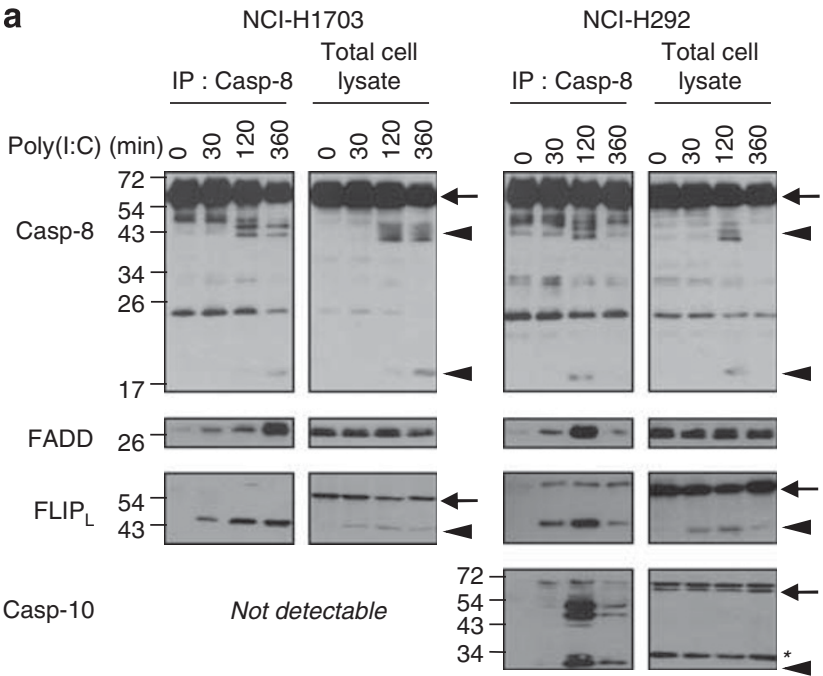

b

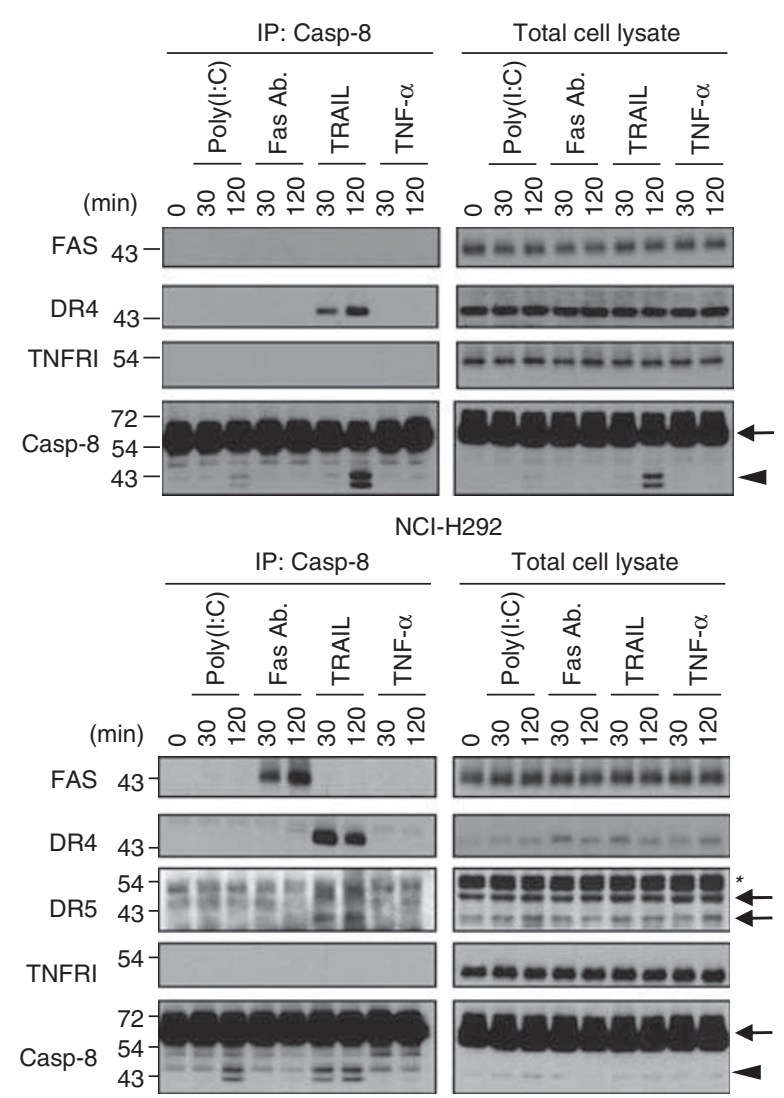

Figure 3 TLR3 activation triggers the formation of a caspase-8-activating complex independent of classical DRs. (a) $\mathrm{NCl}-\mathrm{H} 1703$ and $\mathrm{NCl}-\mathrm{H} 292$ cells were treated with $100 \mu \mathrm{g} / \mathrm{ml}$ Poly $(\mathrm{l}: \mathrm{C})$ for the indicated times, and caspase-8 was immunoprecipitated (IP) and immunoblotted as indicated. Arrows and arrowheads indicate full-length and cleaved proteins, respectively. *Indicates nonspecific band. (b) $\mathrm{NCl}-\mathrm{H} 1703$ and $\mathrm{NCl}-\mathrm{H} 292$ cells were stimulated with $100 \mu \mathrm{g} / \mathrm{ml} \mathrm{Poly}(\mathrm{l}: \mathrm{C})$, $200 \mathrm{ng} / \mathrm{ml}$ anti-Fas antibody clone $\mathrm{CH} 11,200 \mathrm{ng} / \mathrm{ml}$ TRAIL, or $50 \mathrm{ng} / \mathrm{ml}$ TNF- $\alpha$ for the indicated times ( $\mathrm{min}$ ), and caspase-8 immunoprecipitates (IP) and cell lysates were analyzed by immunoblot as indicated. Arrows and arrowheads indicate fulllength and cleaved proteins, respectively. *Indicates nonspecific band caspase-8 were inversely regulated after cIAPs depletion, with cleaved RIP1 becoming the major form in the complex (Figure 7c). Interestingly, the amounts of FADD, TLR3, TRIF, TRAF2, TRADD, and cleaved caspase-10 associated with caspase-8 were also significantly increased in presence of BV6 after TLR3 activation, and caspase-8 cleavage was enhanced. Altogether, these results indicate that clAPs negatively regulate the formation of the pro-apoptotic complex, and suggest that the inhibitory role of IAPs is probably mediated through their ubiquitin ligase activity towards RIP1.

FADD might be dispensable for TLR3-induced apoptosis. The association of FADD with caspase-8 (Figures 3a, 5c, and $7 \mathrm{~b}$ ) suggested that FADD is required for caspase- 8 recruitment to RIP1, according to the model prevailing for TNFRI. ${ }^{24,27}$ However, inhibition of FADD using specific siRNAs failed to prevent TLR3-mediated cell death, whereas it significantly inhibited cell death induced by TRAIL or an antiFas antibody (Figures $8 a$ and b, respectively). Nevertheless, TLR3-triggered death of FADD-depleted cells remained largely (NCl-H1703 cells, Figure $8 \mathrm{c}$ ) or exclusively (NCl-H292 cells, Figure 8d) dependent on caspase activity, as demonstrated by the use of Z-VAD and necrostatin-1. This indicates that cell death remains essentially apoptotic and does not convert to necroptosis. Consistently, while the depletion of FADD was sufficient to prevent the appearance of caspase- 8 and caspase- 3 cleavage products after Fas or TRAILR stimulation, it had no significant effect on TLR3-dependent caspases processing (Figure $8 \mathrm{e}$ ). Taken together, these results suggest that FADD might be dispensable for the recruitment and the activation of caspase-8 in the TLR3-dependent death complex.

\section{Discussion}

Our results provide the first evidences that TLR3, like Fas or TRAILR, can engage the extrinsic apoptotic machinery through the recruitment of caspase- 8 to itself. We propose that dsRNAmediated TLR3 dimerization induces TRIF binding to TLR3 through TIR homotypic interaction allowing recruitment of RIP1 and other components of TNFR machinery, including caspase8 , to trigger apoptosis. Recently, another group has demonstrated that loss of clAPs in HaCat keratinocytes is enough to lead to the formation of a molecular platform termed 'Ripoptosome', which contains RIP1, FADD, cFLIP, caspase-10, and caspase-8, and which can associate with TRIF after Poly(I:C) stimulation to drive either apoptosis or necroptosis. ${ }^{10}$ Requirement for TLR3 was also revealed using siRNA approaches, but interaction of the Ripoptosome with TLR3 in a native complex was lacking. Extending those findings, our results not only unravel the direct binding of a similar machinery to TLR3 but also demonstrate that triggering of a death-signaling complex by stimulation with Poly $(\mathrm{I}: \mathrm{C})$ can occur in the absence of depletion of clAPs or inactivation of proteins involved in survival such as NF- $\kappa \mathrm{B}$ and $c$-FLIP. The presence of RIP1, FADD, cFLIP, and caspase-8 in the complex described here may indicate that the Ripoptosome is recruited to TRIF-TLR3 to signal cell death. However, as we have no indication of Ripoptosome assembling in our cells in the absence of clAPs, our data rather suggest that the death-signaling complex forms 
sequentially in response to TLR3 activation, and that Ripoptosome formation may not be a prerequisite for caspase-8 activation and apoptosis induced by TLR3.

TLR3-mediated apoptosis shows similarities and differences with previously described complexes such as those involved in TNFRI, Fas, TRAILR, and CD40 signaling. Our data strongly suggest that, similar to TNFRI, ${ }^{28}$ RIP1 ubiquitination by clAPs is an important level of modulation of TLR3mediated apoptosis. Whether ubiquitination of RIP1 leads to destabilization of the pro-apoptotic complex or to inhibition of DISC component recruitment requires to be investigated as both conclusions may be drawn from our experimental data. RIP1 ubiquitination at lysine 377 by TRAF2 and clAPs in collaboration with the ubiquitin conjugating enzyme (E2) UbcH5a determines whether TNFRI signals inflammation or cell death in sensitive cancer cells. ${ }^{26,29}$ The detection of TRAF2 and clAP2 together with TRIF in TLR3 signaling complex suggests that polymerization of Lys-63-linked ubiquitin chains on RIP1 could have a similar function. This conclusion is corroborated by (i) the reduced level of ubiquitination of RIP1 in the complex and its greater association with caspase-8 in the presence of Smac mimetic and also (ii) the sensitizing effect of the knockdown of either clAP2 or TRAF2. Along the same line, the enhancement of TLR3-triggered apoptosis when TRADD is depleted could be explained by the involvement of this adapter in the recruitment of TRAF2 to RIP1, as recently suggested for TNFRI. ${ }^{30}$ Indeed, TRADD was shown to be required for RIP1 ubiquitination and for proper NF- $\kappa \mathrm{B}$ and MAP kinase activation in response to TLR3 stimulation. ${ }^{30}$ However, the $\mathrm{N}$-Ter portion of TRIF can also bind TRAF2 directly, irrespective of TRADD. ${ }^{31}$ Thus, as previously reported for TNFRI, ${ }^{27}$ TRADD appears to protect cells from TLR3-triggered apoptosis through a positive regulatory function as regards RIP1 ubiquitination, although the exact mechanism of its action remains to be clarified.

Of note, the cleavage of TRIF, that is likely mediated by caspases, ${ }^{20}$ might represent a first mechanism to limit innate immune and inflammatory genes induction, in particular during apoptosis. Moreover, the disappearance of full-length a

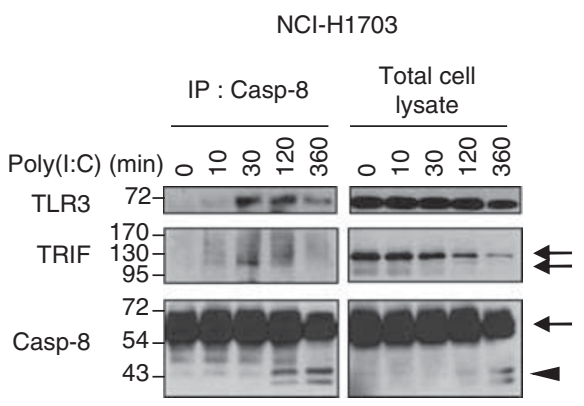

$\mathrm{NCl}-\mathrm{H} 292$

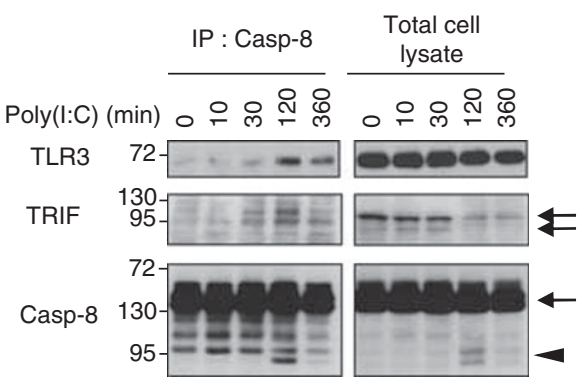

b

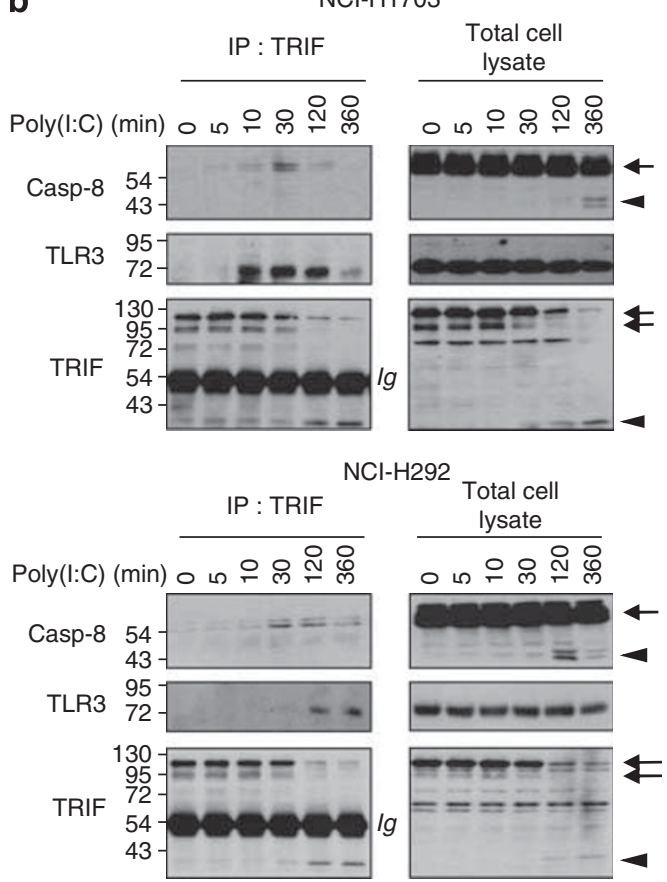

Figure 4 Both TRIF and TLR3 associate with caspase-8 after Poly(l:C) stimulation. (a and $\mathbf{b}) \mathrm{NCl}-\mathrm{H} 1703$ and NCl-H292 cells were stimulated with $100 \mu \mathrm{g} / \mathrm{ml} \mathrm{Poly(l:C)}$ for the indicated times, and caspase-8 (a) or TRIF (b) were immunoprecipitated (IP) and immunoblotted as indicated. Arrows and arrowheads indicate full-length and cleaved proteins, respectively. Ig denotes immunoglobulin heavy chain

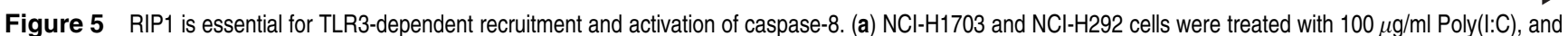
caspase-8 was immunoprecipitated (IP) and immunoblotted with anti-RIP1 antibody. Arrows, filled arrowheads, and open arrowheads point to full-length, cleaved, and modified proteins, respectively. (b) NCl-H1703 and NCl-H292 cells were transfected with two different siRNAs targeting RIP1 (siRIP1 no. 7 and 8 ) for $72 \mathrm{~h}$, exposed to $100 \mu \mathrm{g} / \mathrm{ml}$ Poly $(\mathrm{l}: \mathrm{C})$ for $6 \mathrm{~h}$, and the percentage of annexin $\mathrm{V}^{+}$and $\mathrm{Pl}^{+}$cells was measured. ${ }^{*} P<0.05$ compared with siNS-treated cells plus Poly(l:C); error bars represent S.E.M. of three independent experiments. siRNA-transfected NCl-H1703 and NCl-H292 cells were lysed, and then immunoblotted as indicated. (c) NCl-H292

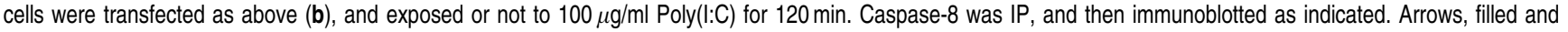
open arrowheads point to full-length, cleaved, and ubiquitinated proteins, respectively. (d) NCl-H292 cells were incubated for $1 \mathrm{~h}$ with $20 \mu \mathrm{M}$ Z-VAD, and exposed or not to $100 \mu \mathrm{g} / \mathrm{ml} \mathrm{Poly}(\mathrm{l}: \mathrm{C})$ for $120 \mathrm{~min}$. Caspase-8 was IP and $20 \%$ of the immunoprecipitate was immunobloted with anti-RIP1 antibody (upper panel). The $80 \%$ remaining was denaturated, re-immunoprecipitated (reIP) with anti-RIP1 antibody, and then immunoblotted as indicated (middle and lower panel). Arrows and open arrowheads point to full-length and ubiquitinated RIP1, respectively. ${ }^{*}$ Indicates nonspecific band 
TRIF after TLR3 activation, even in the absence of apoptosis, could also contribute to the negative control of TLR3 signaling in our cells, as recently reported. ${ }^{32}$
Another intriguing question relates to the actual role of caspase-8-associated FADD in TLR3-triggered apoptosis. FADD possesses both $\mathrm{DD}$ and death effector domain, and is

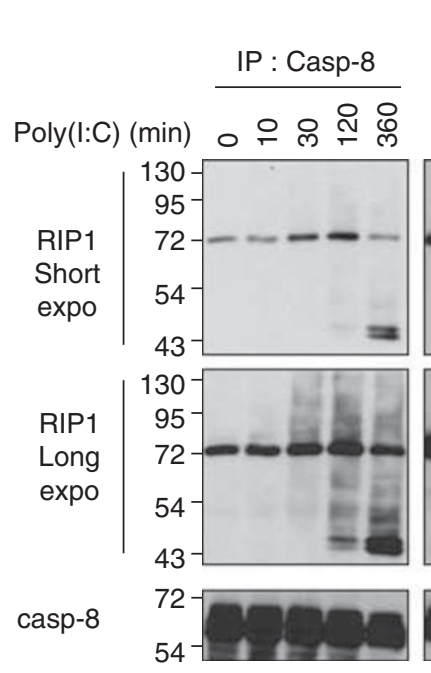

b

$\mathrm{NCl}-\mathrm{H} 1703$
$\mathrm{NCl}-\mathrm{H} 1703$

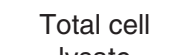

lysate

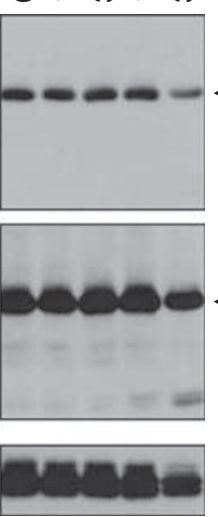

$\mathrm{NCl}-\mathrm{H} 292$

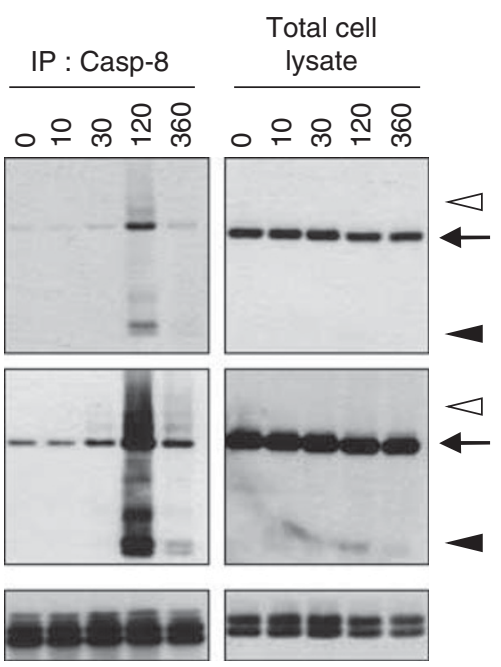

$\mathrm{NCl}-\mathrm{H} 292$

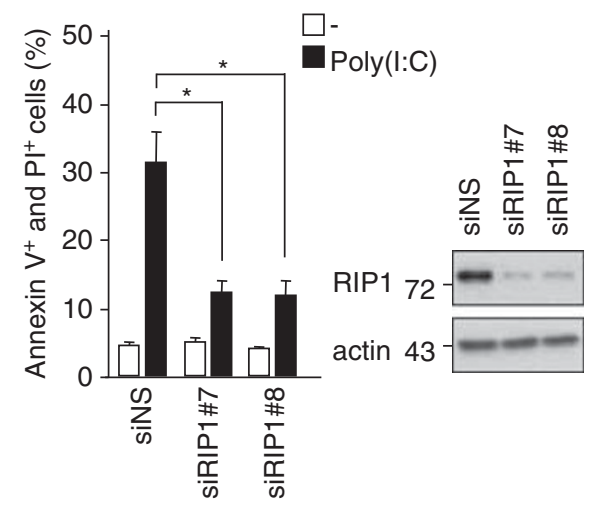

C

\begin{tabular}{|c|c|c|c|c|c|}
\hline \multicolumn{3}{|c|}{ IP : Casp-8 } & \multicolumn{3}{|c|}{$\begin{array}{l}\text { Total cell } \\
\text { lysate }\end{array}$} \\
\hline$\sum_{i}^{\infty}$ & $\begin{array}{l}\text { \# } \\
\frac{\widehat{n}}{\bar{n}}\end{array}$ & 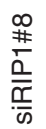 & $\sum_{\infty}^{\infty}$ & $\frac{N}{\frac{\#}{a}}$ & $\begin{array}{l}\infty \\
\stackrel{\infty}{\#} \\
\frac{\square}{\bar{n}}\end{array}$ \\
\hline
\end{tabular}

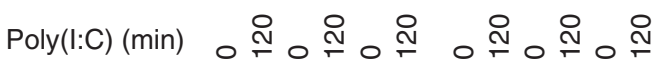

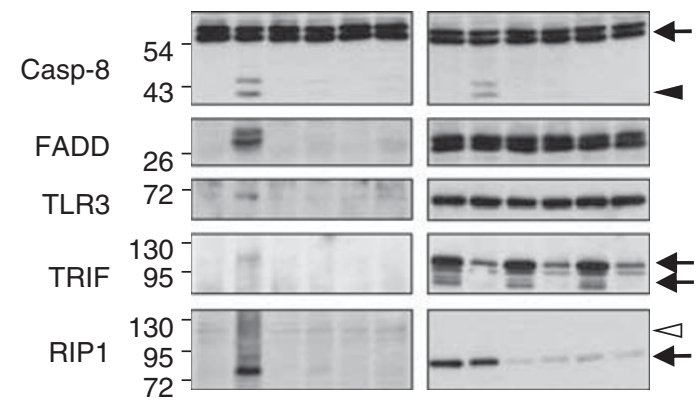

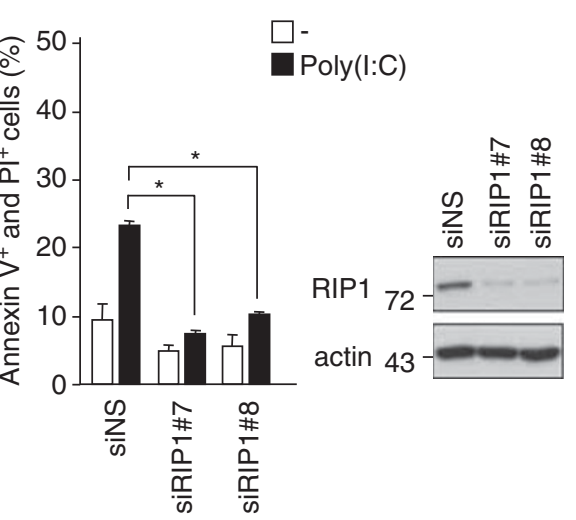

d

$\mathrm{NCl}-\mathrm{H} 292$

DMSO Z-VAD
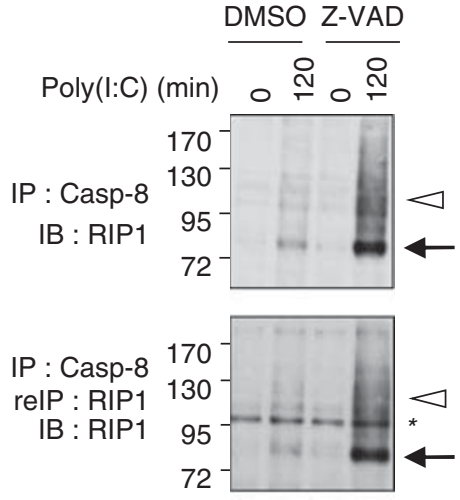

$\left.\begin{array}{lr}170^{-} \\ \text {IP : Casp-8 } & 130 \\ \text { relP : RIP1 } & 95 \\ \text { IB : Ubiquitin } & 72\end{array}\right]$ 
therefore expected to provide the molecular links between RIP1 and caspase-8, as previously suggested by the use of FADD-DN mutant in TNFRI- or ectopic TRIF-induced cell death models. ${ }^{12,13,27}$ However, specific depletion of FADD, that was efficient to block Fas- and TRAILR-dependent apoptosis, provided no protection against TLR3-triggered apoptosis. Similar results were obtained for RIP1-dependent TNFRI- or CD40-induced cell death models, for which FADD a

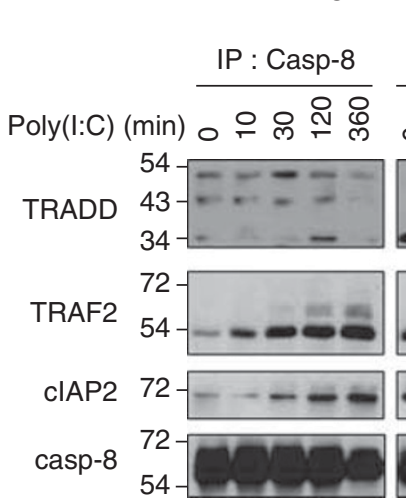

$\mathrm{NCl}-\mathrm{H} 1703$

Total cell lysate 우유용융

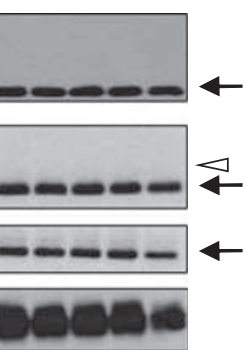

$\mathrm{NCl}-\mathrm{H} 292$

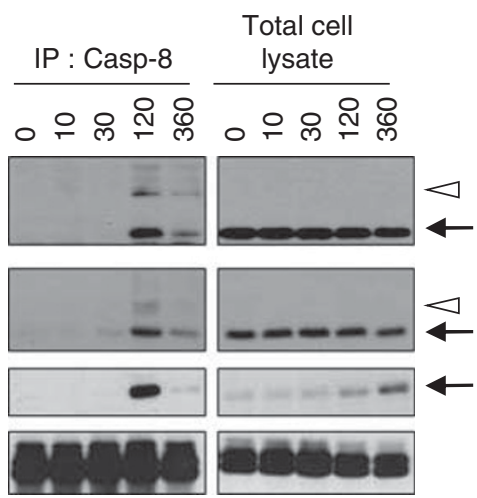

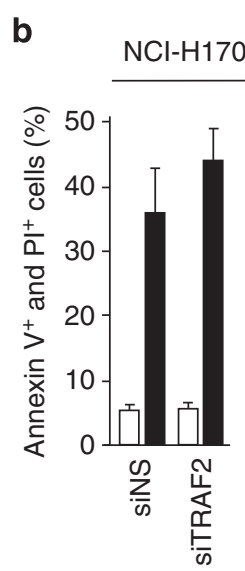

$\square-$

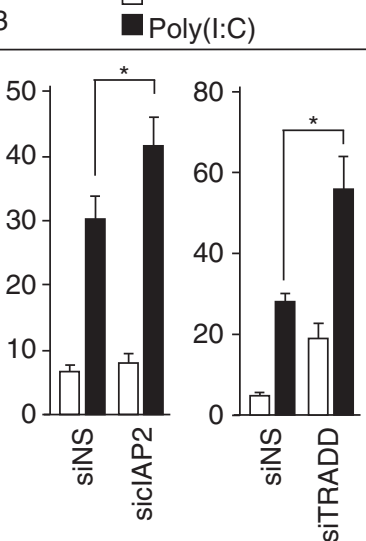

c

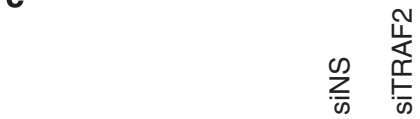

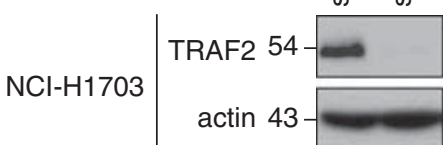
$\mathrm{NCl}-\mathrm{H} 292$

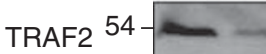
$\operatorname{actin} 43$

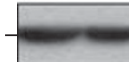$$
\text { . }
$$
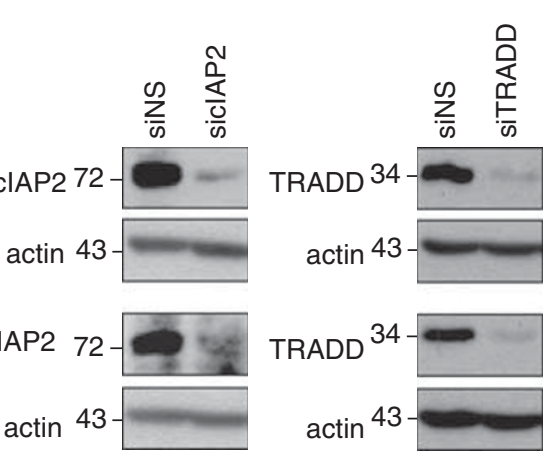

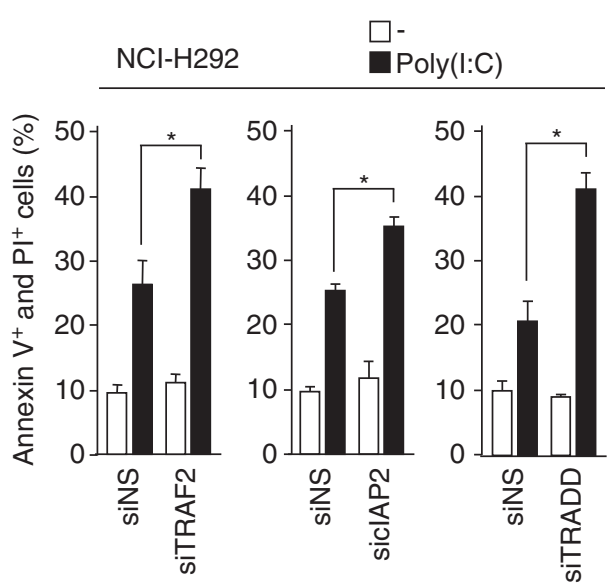

d
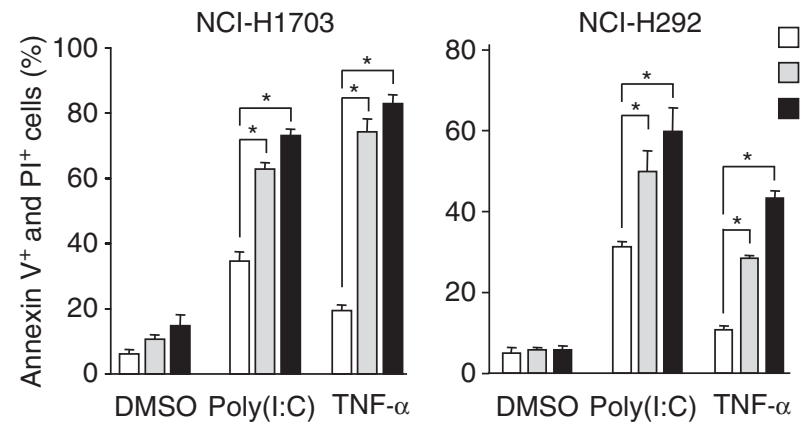

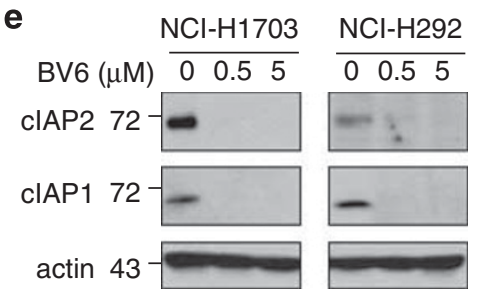


inhibition by siRNA also failed to prevent cell death. ${ }^{27,33}$ Several molecular mechanisms might account for such differences: (i) the stoichiometry of caspase-8/FADD proteins might be drastically different within RIP1-dependent and RIP1-independent death complex, with the low amount of FADD present after siRNA treatment still enabling the recruitment and activation of caspase- 8 in the former but not in the latter; (ii) another adapter (such as $F A F 1^{33}$ ) might exert a redundant function with FADD in RIP1-dependent death complex; and (iii) RIP1 might be associated directly with caspase- 8 without the need for an adapter molecule, as previously observed in vitro. ${ }^{34}$ Obviously, additional work will be required to fully understand the apparent insensitivity of TLR3-triggered apoptosis, and more generally of RIP1dependent cell death, to FADD depletion.
TLR3 also signals inflammation in normal bronchial and nasopharyngeal epithelial cells that, however, appear insensitive to poly(I:C)-induced apoptosis, even in the presence of Smac mimetic (our unpublished data and Friboulet et al. ${ }^{7}$ ). Thus, clAPmediated RIP1 ubiquitination alone is unlikely to explain resistance to TLR3-triggered apoptosis in normal epithelial cells. Rather, ubiquitination of RIP1 may be considered as a timing device, preventing excessive caspase- 8 activation, allowing cell fate decision, similar to c-FLIP and NF-kB activation after TNFRI stimulation. $^{24,35}$ The molecular mechanisms governing the balance between apoptosis and inflammation in cancer cells remains to be fully elucidated, but the selective cytotoxicity and the ability of TLR3 to induce apoptosis independent of the p53 status - $\mathrm{H} 1703$ and $\mathrm{NCl}-\mathrm{H} 292$ cell lines used in our study possess a mutated and wild-type p53, respectively (IARC TP53 database)

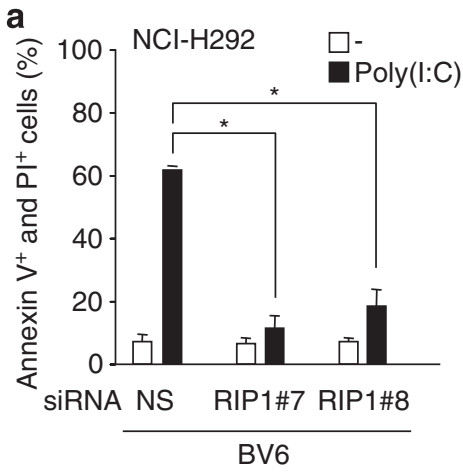

b
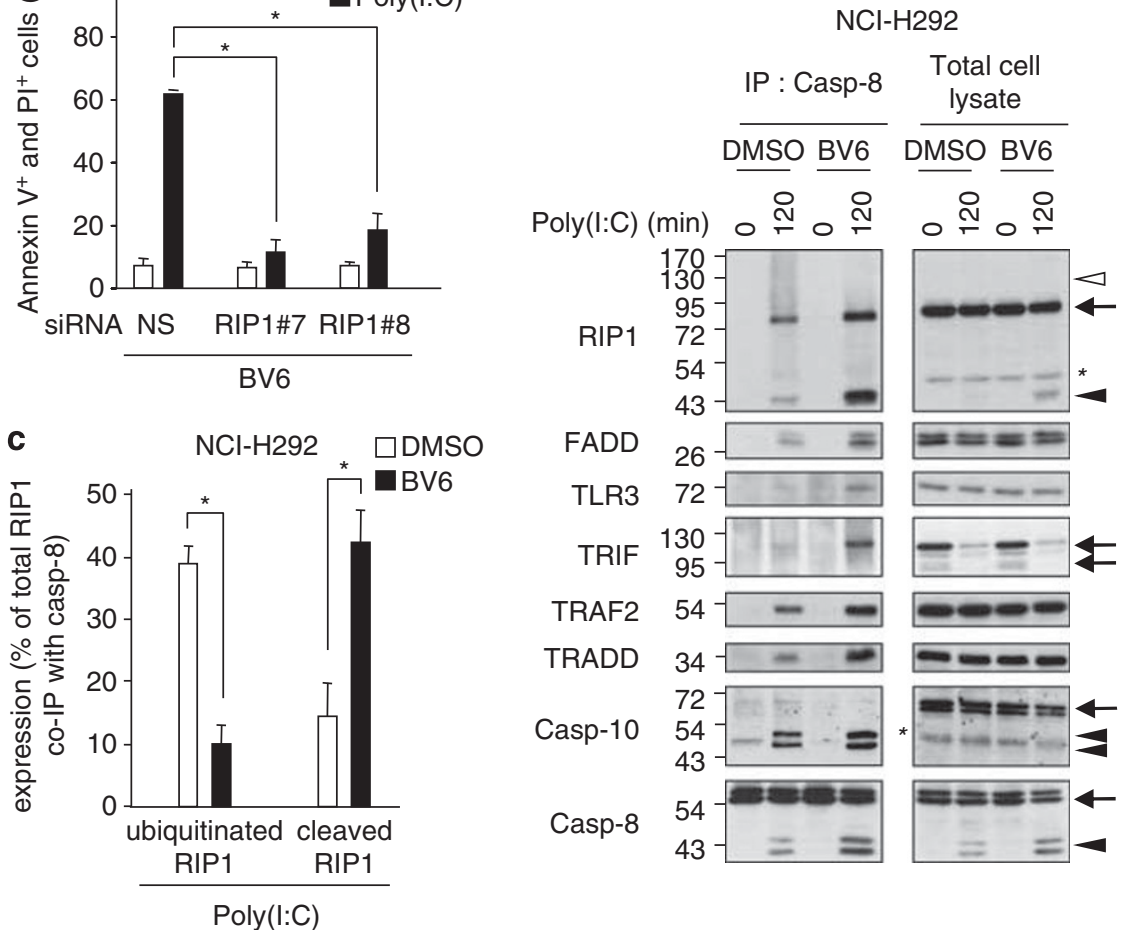

Figure 7 Inhibition of clAPs-dependent RIP1 ubiquitination facilitates the formation of the TLR3-dependent death-signaling complex and the activation of caspase-8. (a) NCl-H292 cells were transfected with two different siRNA targeting RIP1 (siRIP1 no. 7 and 8) for $72 \mathrm{~h}$, incubated for $1 \mathrm{~h}$ with Smac mimetic BV6, and then stimulated with $100 \mu \mathrm{g} / \mathrm{ml} \mathrm{Poly}(\mathrm{l}: \mathrm{C})$ for $6 \mathrm{~h}$. The percentage of annexin $\mathrm{V}^{+}$and $\mathrm{Pl}^{+}$cells was then measured. ${ }^{*} P<0.05$ compared with siNS-treated cells plus Poly(l:C); error bars represent S.E.M. of three independent experiments. (b) NCl-H292 cells were treated $1 \mathrm{~h}$ with $5 \mu \mathrm{M} \mathrm{BV6}$, and exposed or not to $100 \mu \mathrm{g} / \mathrm{ml} \mathrm{Poly}(\mathrm{l}: \mathrm{C})$ for $120 \mathrm{~min}$. Caspase-8 was immunoprecipitated (IP) and then immunoblotted as indicated. Arrows, filled and open arrowheads indicate full-length, cleaved, and ubiquitinated proteins, respectively. *Indicates nonspecific band. (c) Signals obtained in (b) and corresponding to RIP1 associated with caspase-8 following Poly(l:C) treatment were quantified using ImageJ software (NIH, USA; http://rsbweb.nih.gov/ij/index.html). Quantifications of cleaved and ubiquitinated forms of RIP1 are shown and expressed as percentage of total RIP1. ${ }^{\star} P<0.05$; error bars represent S.E.M. of four independent experiments

Figure 6 Inhibition of the ubiquitin ligases TRAF2 and clAPs, and of the adapter TRADD sensitizes to TLR3-triggered apoptosis. (a) NCl-H1703 and NCI-H292 cells were treated with $100 \mu \mathrm{g} / \mathrm{ml} \mathrm{Poly}(\mathrm{l}: \mathrm{C})$ for the indicated times, and caspase-8 was immunoprecipitated (IP) and immunoblotted as indicated. Arrows and open arrowheads indicate full-length and modified proteins, respectively. (b) NCl-H1703 and NCl-H292 cells were transfected with siRNA targeting TRAF2 (siTRAF2), cIAP2 (siclAP2), or TRADD (siTRADD) for $72 \mathrm{~h}$, exposed for $6 \mathrm{~h}$ to $100 \mu \mathrm{g} / \mathrm{ml}$ Poly(l:C), and the percentage of annexin $\mathrm{V}^{+}$and $\mathrm{Pl}^{+}$cells was measured. ${ }^{*} P<0.05$ compared with siNS-treated cells plus Poly(l:C); error bars represent S.E.M. of three independent experiments. (c) siRNA-transfected NCl-H1703 and NCl-H292 cells were lysed, and then immunoblotted as indicated. (d) Percentage of annexin $\mathrm{V}^{+}$and $\mathrm{PI}^{+} \mathrm{NCl}-\mathrm{H} 1703$ and NCl-H292 cells treated for $1 \mathrm{~h}$ with the Smac mimetic BV6 at the indicated concentrations, and then exposed to $100 \mu \mathrm{g} / \mathrm{ml} \mathrm{Poly}(\mathrm{l}: \mathrm{C})$ or $20 \mathrm{ng} / \mathrm{ml} \mathrm{TNF}-\alpha$ for $6 \mathrm{~h}$. ${ }^{*} P<0.05$; error bars represent S.E.M. of three independent experiments. (e) NCl-H1703 and NCl-H292 cells were incubated for $1 \mathrm{~h}$ with the indicated concentrations of Smac mimetic BV6, and then lysed and immunoblotted as indicated 
a

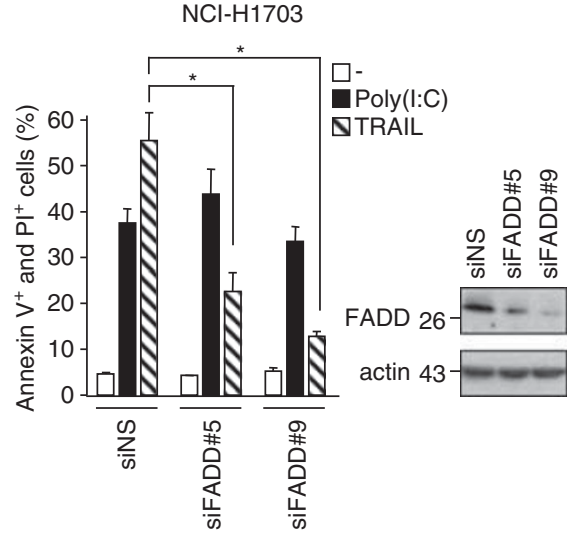

b

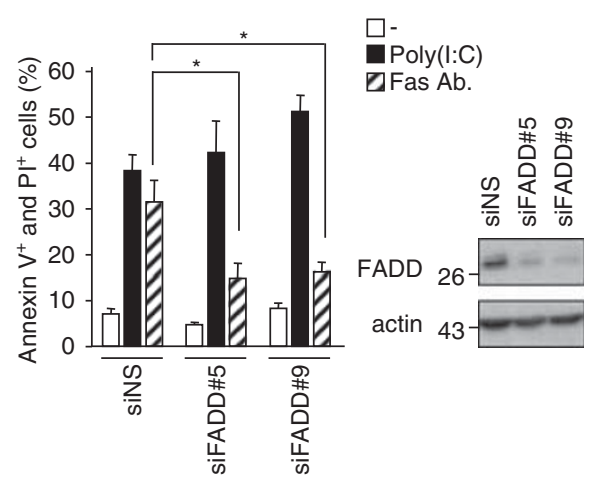

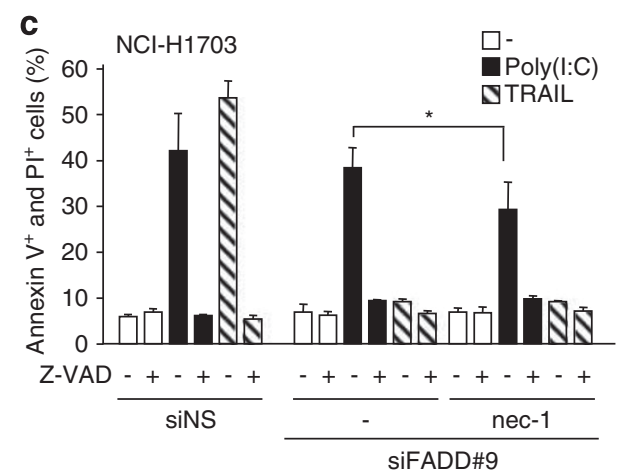

e

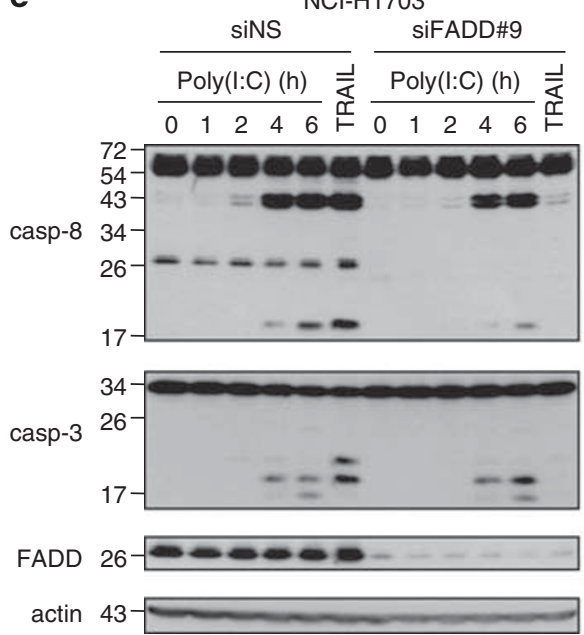

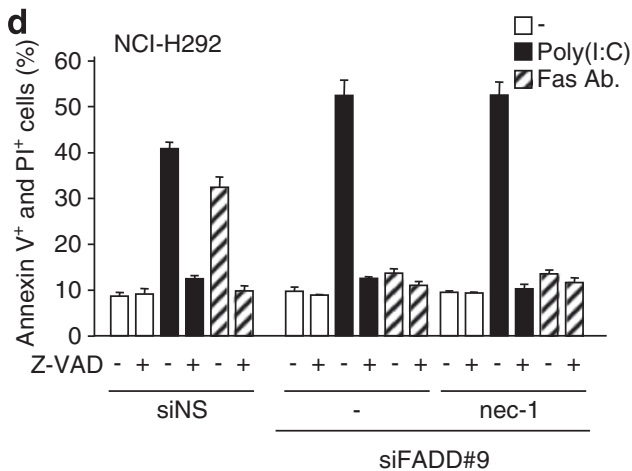

$\mathrm{NCl}-\mathrm{H} 292$

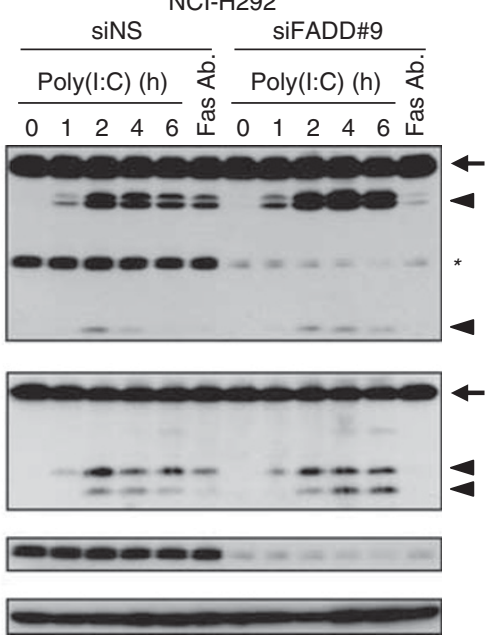

Figure 8 Effect of siRNA targeting FADD treatment on Poly(l:C)-induced apoptosis. (a and $\mathbf{b}) \mathrm{NCl}-\mathrm{H} 1703$ (a) and NCl-H292 (b) cells were transfected with two different siRNA targeting FADD (siFADD no. 5 and 9 ) for $72 \mathrm{~h}$, exposed for $6 \mathrm{~h}$ to $100 \mu \mathrm{g} / \mathrm{ml}$ Poly $(\mathrm{l}: \mathrm{C}$ ) or $200 \mathrm{ng} / \mathrm{ml}$ TRAlL (a) or $200 \mathrm{ng} / \mathrm{ml}$ anti-Fas antibody (b), and the percentage of annexin $\mathrm{V}^{+}$and $\mathrm{PI}^{+}$cells was measured. ${ }^{*} P<0.05$ compared with siNS-transfected cells treated with TRAIL or Fas antibody; error bars represent S.E.M. of three independent experiments. Right panels: siRNA-transfected NCl-H1703 and NCl-H292 cells were lysed, and then immunoblotted as indicated. (c and d) NCl-H1703 (c) and $\mathrm{NCl}-\mathrm{H} 292$ (d) cells were transfected with non-silencing siRNA (siNS) or with the siFADD no. 9 for $72 \mathrm{~h}$. The cells were then treated for $1 \mathrm{~h}$ with $20 \mu \mathrm{M} \mathrm{Z-VAD}$ and/or $30 \mu \mathrm{M}$ necrostatin-1 (nec-1), exposed to $100 \mu \mathrm{g} / \mathrm{ml} \mathrm{Poly}(\mathrm{l}: \mathrm{C})$ for $6 \mathrm{~h}$, and the percentage of annexin $\mathrm{V}^{+}$and $\mathrm{PI}^{+}$cells was measured. ${ }^{*} P<0.05$; error bars represent S.E.M. of three independent experiments. (e) siNS- or siFADD no. 9-transfected NCl-H1703 (left panels) and NCl-H292 (right panels) were treated for increasing times with $100 \mu \mathrm{g} / \mathrm{ml} \mathrm{Poly}(\mathrm{l}: \mathrm{C}$ ) or for $2 \mathrm{~h}$ with $200 \mathrm{ng} / \mathrm{ml}$ TRAIL (for NCl-H1703 cells) or for $2 \mathrm{~h}$ with $200 \mathrm{ng} / \mathrm{ml} \mathrm{Fas} \mathrm{Ab} \mathrm{(for} \mathrm{NCl-H292} \mathrm{cells).} \mathrm{The} \mathrm{cells} \mathrm{were} \mathrm{then} \mathrm{lysed} \mathrm{and} \mathrm{immunoblotted}$ as indicated. Arrows and arrowheads indicate full-length and cleaved proteins, respectively. *Indicates nonspecific band

- suggests that it may be possible to target tumors that have acquired either full or partial resistance to chemotherapy. Moreover, some viruses such as herpesviruses have developed mechanisms to counteract host cell apoptosis induction. For example, cytomegalovirus or herpes simplex virus encode M45 and R1 proteins, respectively, that confer resistance to TNF- $\alpha$ - or Poly(I:C)-induced apoptosis by directly interacting with RIP1. ${ }^{36,37}$ Thus, our findings could also be of particular relevance for the control of virus replication and virus-associated pathologies such as encephalitis. 
More generally, our findings demonstrate that TLR3, much like TNFRI, ${ }^{24}$ can transmit death signal through caspase-8. However, contrary to TNFRI, caspase-8 appears to be physically linked to TLR3 through TRIF/RIP1. Given that other TLRs are also able to trigger apoptosis, ${ }^{38}$ and that caspase- 8 has also non-apoptotic functions, ${ }^{39}$ it is tempting to speculate that related platforms may assemble upon stimulation of these TLRs, for the triggering of apoptosis, but also for the regulation of non-apoptotic signaling activities. Further studies will be required to fully address these questions.

\section{Materials and Methods}

Cell culture and reagents. $\mathrm{NCl}-\mathrm{H} 1703$ and $\mathrm{NCl}-\mathrm{H} 292$ cells were purchased from ATCC (LGC Standards, Molsheim, France) and were grown in RPMI 1640 medium (Life Technologies, Grand Island, NY, USA) supplemented with $10 \%$ fetal bovine serum, Hepes, NaPy, $100 \mathrm{U} / \mathrm{ml}$ penicillin/streptomycin, and $2 \mathrm{mM}$ glutamine. Poly(I:C)-HMW was purchased from Invivogen (San Diego, CA, USA). BafilomycinA1 was purchased from Sigma-Aldrich (St. Louis, MO, USA). Etoposide was a gift of URCC Lyon-Sud (Lyon, France). Z-VAD-FMK, Z-FA-FMK, and TNF- $\alpha$ were from R\&D Systems (Minneapolis, MN, USA). Necrostatin-1 was purchased from SigmaAldrich. TRAIL was from Peprotech (Rocky Hill, NJ, USA), and Smac mimetic BV6 was a gift from Wayne Fairbrother (Genentech, CA, USA).

Antibodies. Goat polyclonal anti-caspase-8 (C-20) and anti-MDA5 antibodies mouse monoclonal IgG2b anti-TNFRI (clone $\mathrm{H}-5$ ) antibody, and rabbit polyclonal anti-FAS (C-20) antibody were purchased from Santa Cruz Biotechnology (Santa Cruz, CA, USA). Rabbit polyclonal anti-RIG-I was from Abcam (Cambridge, UK). Rabbit polyclonal anti-DR4 and anti-DR5 antibodies were from Chemicon (Millipore, Molsheim, France). Mouse monoclonal IgG1 anti-actin (clone C4) antibody was from MP Biomedicals Europe (Illkirch, France). Mouse monoclonal lgG1 anti-Bcl-2 (clone 124) antibody was from DAKO France (Trappes, France). Mouse monoclonal lgG1 anti-clAP2 (clone F30-2285) and IgG2a anti-TRAF2 (clone C90-481) antibodies were from BD Pharmingen (San Diego, CA, USA). Mouse monoclonal IgG1 anti-TRADD (clone 37), IgG1 anti-FADD (clone 1), and IgG2a anti-RIP1 (clone 38) antibodies were purchased from BD Transduction Laboratories (Franklin Lakes, NJ, USA). Mouse monoclonal lgG1 anti-FLIP (clone NF6) antibody was from Alexis Biochemicals (Enzo Life Sciences, Farmingdale, NY, USA). Goat polyclonal antiCIAP1 and blocking anti-TRAIL antibodies, mouse monoclonal IgG1 blocking antiTNF- $\alpha$ (clone 6401), and anti-caspase-9 (clone LAP6) antibodies were from R\&D Systems. Rabbit polyclonal anti-PKR, anti-caspase-3, anti-BID, anti-TRIF antibodies, and mouse monoclonal IgG1 anti-caspase-8 (clone 1C12) and antiubiquitin (clone P4D1) antibody were from Cell Signaling Technology (Danvers, MA, USA). Mouse monoclonal activating lgM anti-Fas (clone $\mathrm{CH}-11$ ), blocking $\lg \mathrm{G} 1$ antiFas (clone ZB4), IgM isotype control (7E10), IgG1 anti-caspase-10 (clone 4C1), and IgG2b anti-caspase-8 (clone 5F7) antibodies were from MBL (Enzo Life Sciences). TLR3.2 monoclonal antibody was generated (in collaboration with Dendritics (Lyon, France)) after immunizing mice with the soluble extracellular domain of human TLR3 (from R\&D Systems). HRP-conjugated donkey anti-mouse, anti-rabbit or antigoat secondary antibodies were from Jackson ImmunoResearch Laboratories (West Grove, PA, USA). HRP-conjugated goat anti-mouse IgG1, IgG2a, or IgG2b secondary antibodies were from SouthernBiotech (Birmingham, AL, USA).

Western blotting and co-immunoprecipitation. Cells were lysed in cold lysis buffer (20 mM Tris- $\mathrm{HCl}$ (pH 7.4), $150 \mathrm{mM} \mathrm{NaCl}, 0.2 \%$ Nonidet NP40) supplemented with $1 \mathrm{mM}$ orthovanadate, $10 \mathrm{mM} \mathrm{NaF}$, and a protease inhibitor cocktail (Sigma-Aldrich) for 25 min on ice. Cell lysates were cleared by centrifugation ( $13000 \mathrm{~g}, 10 \mathrm{~min}, 4^{\circ} \mathrm{C}$ ), and protein concentration was determined by the Bradford assay (Bio-Rad, Hercules, CA, USA). Proteins were resolved on SDSPAGE, transferred onto PVDF membranes by electroblotting, and nonspecific binding sites were blocked using Tris-buffered saline containing $0.1 \%$ Tween-20 and $5 \%(\mathrm{w} / \mathrm{v})$ dry milk or BSA. After incubation with appropriate secondary antibodies conjugated to horseradish peroxidase, blots were revealed using the ECL reagents (GE Healthcare, Chalfont St. Giles, UK).

For co-immunoprecipitation experiments, cells were cultured in $100-\mathrm{mm}$ or 150-mm dishes, stimulated, collected, washed in PBS, and lysed in $500 \mu \mathrm{l}$ or 1 -ml cold lysis buffer, respectively. Lysis buffer was supplemented as above plus $20 \mu \mathrm{M}$ Z-VAD-FMK, and plus $N$-ethylmaleimide (Sigma-Aldrich) for ubiquitination analysis. Lysates were precleared with $20 \mu$ l Sepharose-6B or protein G-Sepharose fast Flow (Sigma-Aldrich) for $1 \mathrm{~h}$ at $4^{\circ} \mathrm{C}$ and then immunoprecipitated overnight at $4{ }^{\circ} \mathrm{C}$ with $2 \mu \mathrm{g}$ of either goat anti-caspase-8 antibodies or rabbit anti-TRIF antibodies in the presence of $20-\mu \mathrm{l}$ protein G-Sepharose for $2 \mathrm{~h}$ or overnight at $4{ }^{\circ} \mathrm{C}$. Beads were recovered by centrifugation, and immunoprecipitates were extensively washed with lysis buffer and eluted with SDS loading buffer by boiling for $5 \mathrm{~min}$. Alternatively, caspase-8 immunoprecipitation was also performed with $\mu \mathrm{MACS}$ protein $\mathrm{G}$ microbeads (Miltenyl Biotec GmbH, Bergisch Gladbach, Germany) according to the manufacturer's recommendations. Briefly, cells were lysed as above and then incubated 30 min at $4{ }^{\circ} \mathrm{C}$ with $50 \mu \mathrm{l} \mu \mathrm{MACS}$ protein $\mathrm{G}$ microbeads and $2 \mu \mathrm{g}$ of goat anti-caspase-8 antibody. Cell lysates were applied onto $\mu$ Columns placed in the magnetic field of the $\mu$ MACS Separator (Miltenyl Biotec $\mathrm{GmbH}$ ). Columns were then rinsed five times with lysis buffer, and immunoprecipitates were eluted with preheated $\left(95^{\circ} \mathrm{C}\right)$ SDS loading buffer. For re-immunoprecipitation experiments, caspase-8 immunoprecipitates were eluted with pre-heated lysis buffer containing $1 \%$ SDS and $5 \mathrm{mM} \mathrm{DTT} ; 20 \%$ of each sample was resolved by SDS-PAGE, and the remaining $80 \%$ was diluted 10 -fold in lysis buffer and then re-immunoprecipitated with anti-RIP1 antibody, and resolved by SDS-PAGE.

Quantitation of live cell recovery and apoptosis. For live cell recovery measurement, $1 \times 10^{4}$ cells seeded in 96-well plates were cultured for $24 \mathrm{~h}$ and then treated as indicated before adding $20 \mu /$ well of MTS (CellTiter 96 AQueous Non-Radioactive Cell Proliferation Assay reagents, Promega, Madison, WI, USA). Plates were incubated $2 \mathrm{~h}$ at $37^{\circ} \mathrm{C}$ in the dark and absorbance was recorded at $470 \mathrm{~nm}$ and $690 \mathrm{~nm}$ using a Multiskan EX microplate photometer (Thermo Scientific, Pittsburg, PA, USA). A 690-nm wavelength absorbance was used to subtract background. For apoptosis measurement, cells harvested by trypsinization were washed with PBS, and resuspended in annexin $\mathrm{V}$ binding buffer $(10 \mathrm{mM}$ Hepes/ $\mathrm{NaOH}, \mathrm{pH} 7.4,140 \mathrm{mM} \mathrm{NaCl}, 2.5 \mathrm{mM} \mathrm{CaCl}_{2}$ ) containing annexin V-FITC and PI (Abcys, Paris, France). FITC- and PI-labeled cell populations were analyzed by flow cytometry (FACSCalibur, Becton Dickinson, Franklin Lakes, NJ, USA) with CellQuest software (Bekton Dickinson), and expressed as percentage.

RNA interference. Synthetic MDA5 (L-013041-00-0005), RIG-I (L-012511-000005), RIP1 no. 7 (J-004445-07), RIP1 no. 8 (J-004445-08), TLR3 (L-007745-00-0005), TRIF (L-012833-00-0005), and control non-silencing (D-001810-03-20) siRNAs were from Dharmacon (Thermo Scientific). Synthetic PKR (SI00288232), caspase-8 (SI02661946), caspase-9 (SI00299600), cIAP2 (SI02661918), TRADD (SI03098942), TRAF2 (SI02644579), FADD no. 5 (SI00300223), and FADD no. 9 (SI03649016) siRNAs were from Qiagen ( $\mathrm{GmbH}$, Hilden, Germany). Cells were transfected with siRNA using HiPerFect reagents (Qiagen) for 72 to $144 \mathrm{~h}$. The final siRNAs concentrations varied from $5 \mathrm{nM}$ to $100 \mathrm{nM}$ according to cell lines and targeted proteins.

Cell transduction. The retroviral vectors pMSCV-puro-c-FLIP-long and pMSCV-Bcl-xL (Addgene plasmid N ${ }^{\circ} 8790$, Addgene, Cambridge, MA, USA) were used for the ectopic expression of c-FLIP long and Bcl-xL. Pseudotype viruses were generated from the packaging cell line GP2-293 from Clontech (Mountain View, CA, USA). Cells were transduced for $16 \mathrm{~h}$ with viral supernatants containing polybrene $(8 \mathrm{mg} / \mathrm{ml})$, washed in phosphate-buffered saline, and selected in complete medium containing puromycine $(2.5 \mathrm{mg} / \mathrm{ml})$ for 7 days. Bcl-2-expressing cells were obtained using the pBabe-Blasticidin vector (Addgene) as above. Transduced cells were then selected with blasticidin $(2.5 \mu \mathrm{g} / \mathrm{ml})$

Stable cell transfection. NCl-H292 cells were transfected with pcDNA-Bcl-2 (a gift from $\mathrm{P}$ Mehlen, CLB, Lyon, France) using FuGENE transfection reagent (Promega) and according to the manufacturer's recommendations. The FuGENE reagent $(\mu \mathrm{l})$ : DNA $(\mu \mathrm{g})$ ratio 3:1 was used. Cell population resistant to G418 was used for the experiments.

Statistics. Results are expressed as the mean \pm s.e.m. and statistical analysis was performed by two-tailed unpaired Student's $t$-test. A $P<0.05$ was considered significant.

\section{Conflict of Interest}

The authors declare no conflict of interest.

Acknowledgements. We thank our colleagues who provided reagents, especially Patrick Mehlen for the Bcl-2-expressing plasmid, Wayne Fairbrother for 
the gift of Smac mimetic BV6, Isabelle Grosjean for her assistance with cultures, Stéphanie Brunet-Manquat and Isabelle Durand for their support with flow cytometry, Jean-Paul Pais De Barros for assistance with size-exclusion chromatography, and our colleagues in the laboratory for their restless support and encouragement. The Cancéropole Lyon Auvergne Rhone-Alpes (CLARA) funded the work and SL was supported by a grant from the Hospices Civils de Lyon. OM was supported by grants from the ANR (Agence Nationale de la Recherche 07PCV-0031) and the European Community (ApopTrain Marie Curie RTN). GJ and NL were supported by fellowships from the Ligue Nationale contre le Cancer and a joint INSERM and Conseil Régional de Bourgogne fellowship, respectively. We gratefully acknowledge the help and advice of Nicolas Foray.

\section{Author Contributions}

YE, FT, FV, OM, and SL conceived and designed the experiments. YE, FT, FV, GJ, $M B, A P, B V, N L$, and PM-G performed the experiments and data analysis. TR, BS, and YP contributed to data analysis, discussions, and intellectual input. YE, FT, $\mathrm{FV}, \mathrm{OM}$, and SL wrote the paper with all authors providing detailed comments and suggestions. SL directed the project.

1. Levy HB, Law LW, Rabson AS. Inhibition of tumor growth by polyinosinic-polycytidylic acid. Proc Natl Acad Sci USA 1969; 62: 357-361.

2. Kalai M, Van Loo G, Vanden Berghe T, Meeus A, Burm W, Saelens X et al. Tipping the balance between necrosis and apoptosis in human and murine cells treated with interferon and dsRNA. Cell Death Differ 2002; 9: 981-994.

3. Takeuchi O, Akira S. Innate immunity to virus infection. Immunol Rev 2009; 227: 75-86.

4. Funami K, Sasai M, Ohba Y, Oshiumi H, Seya T, Matsumoto M. Spatiotemporal mobilization of Toll/L-1 receptor domain-containing adaptor molecule-1 in response to dsRNA. J Immunol 2007; 179: 6867-6872.

5. Salaun B, Coste I, Rissoan MC, Lebecque SJ, Renno T. TLR3 can directly trigger apoptosis in human cancer cells. J Immunol 2006; 176: 4894-4901.

6. Salaun B, Lebecque S, Matikainen S, Rimoldi D, Romero P. Toll-like receptor 3 expressed by melanoma cells as a target for therapy? Clin Cancer Res 2007; 13: 4565-4574.

7. Friboulet L, Pioche-Durieu C, Rodriguez S, Valent A, Souquere $\mathrm{S}$, Ripoche $\mathrm{H}$ et al. Recurrent overexpression of C-IAP2 in EBV-associated nasopharyngeal carcinomas: critical role in resistance to Toll-like receptor 3-mediated apoptosis. Neoplasia 2008; 10: 1183-1194.

8. Salaun B, Zitvogel L, Asselin-Paturel C, Morel Y, Chemin K, Dubois C et al. TLR3 as a biomarker for the therapeutic efficacy of double-stranded RNA in breast cancer. Cancer Res 2011; 71: 1607-1614.

9. Weber A, Kirejczyk Z, Besch R, Potthoff S, Leverkus M, Hacker G. Proapoptotic signalling through Toll-like receptor-3 involves TRIF-dependent activation of caspase-8 and is under the control of inhibitor of apoptosis proteins in melanoma cells. Cell Death Differ 2009; 17: 942-951.

10. Feoktistova M, Geserick P, Kellert B, Dimitrova DP, Langlais $C$, Hupe M et al. clAPs block ripoptosome formation, a RIP1/caspase-8 containing intracellular cell death complex differentially regulated by cFLIP isoforms. Mol Cell 2011; 43: 449-463.

11. Meylan E, Burns K, Hofmann K, Blancheteau V, Martinon F, Kelliher M et al. RIP1 is an essential mediator of Toll-like receptor 3-induced NF-kappa B activation. Nat Immunol 2004; 5: 503-507.

12. Ruckdeschel K, Pfaffinger G, Haase R, Sing A, Weighardt H, Hacker G et al. Signaling of apoptosis through TLRs critically involves Toll/L-1 receptor domain-containing adapter inducing IFN-beta, but not MyD88, in bacteria-infected murine macrophages. J Immunol 2004; 173: 3320-3328.

13. Kaiser WJ, Offermann MK. Apoptosis induced by the Toll-like receptor adaptor TRIF is dependent on its receptor interacting protein homotypic interaction motif. J Immunol 2005; 174: 4942-4952.

14. Tenev $T$, Bianchi K, Darding M, Broemer M, Langlais $C$, Wallberg $F$ et al. The ripoptosome, a signaling platform that assembles in response to genotoxic stress and loss of IAPs. Mol Cell 2011; 43: 432-448.

15. Zhang Z, Kim T, Bao M, Facchinetti V, Jung SY, Ghaffari AA et al. DDX1, DDX21, and DHX36 helicases form a complex with the adaptor molecule TRIF to sense dsRNA in dendritic cells. Immunity 2011; 34: 866-878.
16. Xu LG, Wang YY, Han KJ, Li LY, Zhai Z, Shu HB. VISA is an adapter protein required for virus-triggered IFN-beta signaling. Mol Cell 2005; 19: 727-740.

17. Degterev A, Hitomi J, Germscheid M, Ch'en IL, Korkina O, Teng X et al. Identification of RIP1 kinase as a specific cellular target of necrostatins. Nat Chem Biol 2008; 4: 313-321.

18. Scaffidi C, Schmitz I, Krammer PH, Peter ME. The role of C-FLIP in modulation of CD95induced apoptosis. J Biol Chem 1999; 274: 1541-1548.

19. Micheau O, Thome M, Schneider P, Holler N, Tschopp J, Nicholson DW et al. The long form of FLIP is an activator of caspase-8 at the Fas death-inducing signaling complex. J Biol Chem 2002; 277: 45162-45171.

20. Rebsamen M, Meylan E, Curran J, Tschopp J. The antiviral adaptor proteins Cardif and Trif are processed and inactivated by caspases. Cell Death Differ 2008; 15 1804-1811.

21. Lin $Y$, Devin A, Rodriguez $Y$, Liu ZG. Cleavage of the death domain kinase RIP by caspase-8 prompts TNF-induced apoptosis. Genes Dev 1999; 13: 2514-2526.

22. Legler DF, Micheau O, Doucey MA, Tschopp J, Bron C. Recruitment of TNF receptor 1 to lipid rafts is essential for TNFalpha-mediated NF-kappaB activation. Immunity 2003; 18: 655-664.

23. Ea CK, Deng L, Xia ZP, Pineda G, Chen ZJ. Activation of IKK by TNFalpha requires sitespecific ubiquitination of RIP1 and polyubiquitin binding by NEMO. Mol Cell 2006; 22: 245-257.

24. Micheau O, Tschopp J. Induction of TNF receptor I-mediated apoptosis via two sequential signaling complexes. Cell 2003; 114: 181-190.

25. Varfolomeev E, Blankenship JW, Wayson SM, Fedorova AV, Kayagaki N, Garg P et al. IAP antagonists induce autoubiquitination of C-IAPs, NF-kappaB activation, and TNFalpha-dependent apoptosis. Cell 2007; 131: 669-681.

26. O'Donnell MA, Legarda-Addison D, Skountzos P, Yeh WC, Ting AT. Ubiquitination of RIP1 regulates an NF-kappaB-independent cell-death switch in TNF signaling. Curr Biol 2007; 17: 418-424.

27. Wang L, Du F, Wang $X$. TNF-alpha induces two distinct caspase-8 activation pathways. Cell 2008; 133: 693-703.

28. O'Donnell MA, Ting AT. RIP1 comes back to life as a cell death regulator in TNFR1 signaling. FEBS J 2011; 278: 877-887.

29. Varfolomeev E, Goncharov T, Fedorova AV, Dynek JN, Zobel K, Deshayes K et al. c-IAP1 and C-IAP2 are critical mediators of tumor necrosis factor alpha (TNFalpha)-induced NF-kappaB activation. J Biol Chem 2008; 283: 24295-24299.

30. Ermolaeva MA, Michallet MC, Papadopoulou N, Utermohlen O, Kranidioti K, Kollias G et al. Function of TRADD in tumor necrosis factor receptor 1 signaling and in TRIF-dependent inflammatory responses. Nat Immunol 2008; 9: 1037-1046.

31. Sasai M, Tatematsu M, Oshiumi H, Funami K, Matsumoto M, Hatakeyama $S$ et al. Direct binding of TRAF2 and TRAF6 to TICAM-1/TRIF adaptor participates in activation of the Toll-like receptor 3/4 pathway. Mol Immunol 2010; 47: 1283-1291.

32. Tao S, Zhu L, Lee P, Lee WM, Knox K, Chen J et al. Negative control of TLR3 signaling by TICAM1 downregulation. Am J Respir Cell Mol Biol 2011; e-pub ahead of print 28 December 2011.

33. Knox PG, Davies CC, loannou M, Eliopoulos AG. The death domain kinase RIP1 links the immunoregulatory CD40 receptor to apoptotic signaling in carcinomas. J Cell Biol 2011; 192: 391-399.

34. Shikama Y, Yamada M, Miyashita T. Caspase-8 and caspase-10 activate NF-kappaB through RIP, NIK and IKKalpha kinases. Eur J Immunol 2003; 33: 1998-2006.

35. Micheau O, Lens S, Gaide O, Alevizopoulos K, Tschopp J. NF-kappaB signals induce the expression of c-FLIP. Mol Cell Biol 2001; 21: 5299-5305.

36. Upton JW, Kaiser WJ, Mocarski ES. Cytomegalovirus M45 cell death suppression requires receptor-interacting protein (RIP) homotypic interaction motif (RHIM)-dependent interaction with RIP1. J Biol Chem 2008; 283: 16966-16970.

37. Dufour F, Bertrand L, Pearson A, Grandvaux N, Langelier Y. The ribonucleotide reductase R1 subunits of herpes simplex virus types 1 and 2 protect cells against poly(l:C)-induced apoptosis. J Virol 2011; 85: 8689-8701.

38. Salaun B, Romero P, Lebecque S. Toll-like receptors' two-edged sword: when immunity meets apoptosis. Eur J Immunol 2007; 37: 3311-3318.

39. Maelfait J, Beyaert R. Non-apoptotic functions of caspase-8. Biochem Pharmacol 2008; 76: 1365-1373.

40. Ewald SE, Engel A, Lee J, Wang M, Bogyo M, Barton GM. Nucleic acid recognition by Toll-like receptors is coupled to stepwise processing by cathepsins and asparagine endopeptidase. J Exp Med 2011; 208: 643-651.

\section{Supplementary Information accompanies the paper on Cell Death and Differentiation website (http://www.nature.com/cdd)}

